Parte III - Perspectivas e experiências

\title{
Estudantes agindo para abordar danos pessoais, sociais e ambientais relacionados à ciência e à tecnologia
}

\author{
Larry Bencze \\ Sarah El Halwany \\ Mirjan Krstovic \\ Minja Milanovic \\ Christina Phillips \\ Majd Zouda
}

\section{SciELO Books / SciELO Livros / SciELO Libros}

BENCZE, L., EL HALWANY, S., KRSTOVIC, M., MILANOVIC, M., PHILLIPS, C., and ZOUDA, M. Estudantes agindo para abordar danos pessoais, sociais e ambientais relacionados à ciência e à tecnologia. In: CONRADO, D.M., and NUNES-NETO, N. Questões sociocientíficas: fundamentos, propostas de ensino e perspectivas para ações sociopolíticas [online]. Salvador: EDUFBA, 2018, pp. 515-559. ISBN 978-85232-2017-4. https://doi.org/10.7476/9788523220174.0025. \section{International license.}

All the contents of this work, except where otherwise noted, is licensed under a Creative Commons Attribution 4.0

Todo o conteúdo deste trabalho, exceto quando houver ressalva, é publicado sob a licença Creative Commons Atribição $\underline{4.0}$. 


\title{
ESTUDANTES AGINDO PARA ABORDAR DANOS PESSOAIS, SOCIAIS E AMBIENTAIS RELACIONADOS À CIÊNCIA E À TECNOLOGIA ${ }^{1}$
}

\author{
Larry Bencze \\ Sarah El Halwany \\ Mirjan Krstovic \\ Minja Milanovic \\ Christina Phillips \\ Majd Zouda
}

\section{Introdução: problemas e ações sobre CTSA}

Muitas pessoas concordam que os campos da ciência e da tecnologia têm tido numerosos efeitos positivos no Bem-Estar dos Indivíduos, Sociedades e Ambientes (WISE)2.

1 O texto original foi produzido em inglês pelos autores. A tradução para o português foi realizada por Nei Nunes-Neto. (N. do O.).

2 Nota do tradutor: decidimos, no texto traduzido em português, manter a expressão WISE, acrônimo do inglês Wellbeing of Individuals, Societies and Environments, para a referência a bem-estar dos indivíduos, sociedades e ambientes, por ser esta expressão já bem conhecida como parte do modelo proposto por Larry Bencze. 
Em alguns contextos, os seres humanos desfrutam de longos períodos de vida, por exemplo, em grande parte por causa de avanços em ciências da vida, medicina e agricultura. Há aqueles que afirmam o contrário, no entanto. Muitos apontam, por exemplo, a mudança do clima como o nosso problema mais premente. (KLEIN, 2014) De acordo com o Painel Intergovernamental para as Mudanças Climáticas, ${ }^{3}$ a Terra está a caminho de uma perda catastrófica da vida e de colapsos físicos, a menos que mudanças drásticas nas políticas públicas e práticas de instituições privadas sejam feitas nos próximos poucos anos. Há muitos outros problemas potenciais, no entanto - incluindo preocupações com a saúde e de justiça social em matéria de: comida rápida (fast food; por exemplo, frango frito) e outros alimentos processados (por exemplo, os biscoitos com gorduras trans), medicamentos (por exemplo, as drogas com efeitos colaterais negativos), diversas biotecnologias (por exemplo, sementes com um gene que as tornam estéreis), produtos químicos tóxicos para tarefas do dia a dia (por exemplo, o bisfenol A em garrafas de plástico) e pesquisa e práticas agrícolas (por exemplo, agrotóxicos).

Figura 1 - Modelo para as relações entre Ciência, Tecnologia, Sociedade e Ambiente (CTSA)

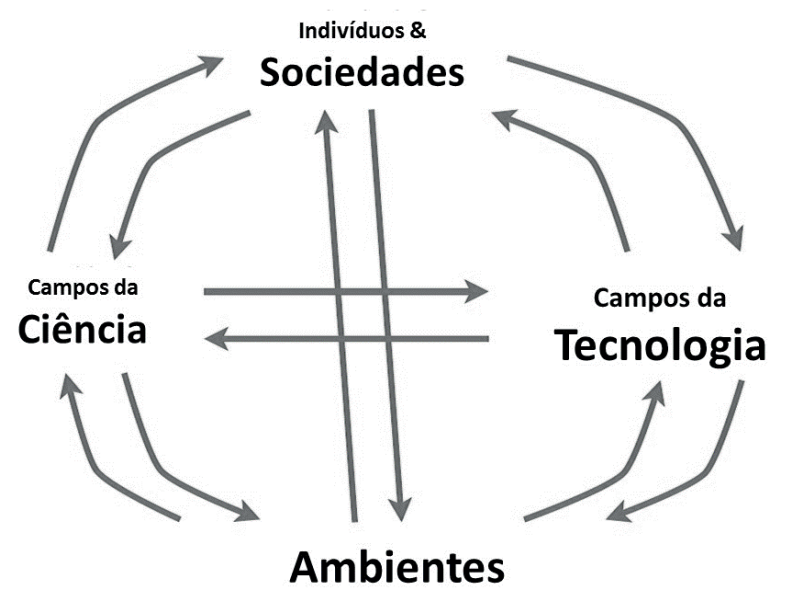

Todas as relações acima podem ser consideradas 'positivas', 'negativas' ou 'neutras'

Fonte: Bencze (2017, p. 29).

Talvez, em reconhecimento aos muitos danos potenciais para o WISE, associados aos campos da ciência e da tecnologia, os sistemas de ciência escolar, pelo menos durante os últimos 40 anos, têm colocado alguma ênfase em aulas e atividades em educação científica que envolvem a consideração das relações, como mostrado na Figura 1, entre os campos profissionais da Ciência e da Tecnologia (e da engenharia) e as Sociedades e os Ambientes. (CTSA) (PEDRETTI; NAZIR, 2011) Ao fazê-lo, tem havido uma tendência para se concentrar em controvérsias em tais relações - por exemplo, como se deve ou

3 Ver em: <www.ipcc.ch>. 
não desregulamentar usos das empresas químicas de ingredientes potencialmente tóxicos em limpeza doméstica e produtos de higiene. (LEONARD, 2010) Um movimento popular relacionado envolve o foco sobre as chamadas Questões Sociocientíficas (QSC), isto é, controvérsias sociais com base nos campos da ciência. Embora pareça haver muitas maneiras de engajar os estudantes em questões/controvérsias, os estudantes são frequentemente encorajados a considerar dados, conclusões e reivindicações de várias partes interessadas (stakeholders) (por exemplo, cientistas e políticos) e negociar com os colegas as suas posições pessoais sobre as questões. (LEVINSON, 2013) Tais abordagens de escolha pessoal para a educação baseada em QSC, aparentemente, têm levado a alguns benefícios significativos para os estudantes - incluindo o desenvolvimento de habilidades para raciocínios sociocientíficos (SADLER; BARAB; SCOTT, 2007) e a aprendizagem sobre a Natureza da Ciência - NdC, em inglês NoS para Nature of Science. (KHISHFE; LEDERMAN, 2006)

Apesar de alguns ganhos educacionais associados ao engajamento dos estudantes nas tomadas de decisão pessoais e bem informadas em questões sobre CTSA, limitar a educação baseada em QSC a abordagens de escolhas pessoais pode ser problemático. De acordo com Levinson (2010, 2013), por exemplo, práticas comuns envolvendo QSC, tendem a colocar os estudantes em papéis que enfatizam a dependência com relação a cientistas e outros especialistas para fornecer informações necessárias para a sua tomada de decisão. Tais papéis de escolha pessoal podem ser apropriados para a cidadania nas democracias representativas - em que os cidadãos exercem escolhas democráticas em grande parte através de eleição periódica dos representantes políticos, muitas vezes informados por especialistas, como cientistas, engenheiros, advogados e outros profissionais. (WOOD, 1998) Alguns estudiosos e outros sugerem, porém, que a educação científica precisa ajudar a preparar as pessoas para uma cidadania mais ativa em formas participativas de democracia. (BENCZE; ALSOP, 2014; HODSON, 2011) Por um lado, parece razoável deixar as decisões sobre questões de ciência e tecnologia para especialistas, que são altamente treinados e têm acesso a equipamentos sofisticados etc. Por outro lado, algumas pessoas estão preocupadas com as influências que membros poderosos das sociedades têm sobre os campos da ciência e da tecnologia, que frequentemente parecem resultar em vários efeitos nocivos sobre o bem-estar dos indivíduos, sociedades e/ou ambientes. (MIROWSKI, 2011) Em muitos lugares do mundo, por exemplo, as empresas têm direitos para minimizar os seus custos, a fim de maximizar os lucros. (MCMURTRY, 2013) Isto pode significar reduções nos custos do trabalho, em fases de extração de recursos, por meio de transporte, vendas e marketing, assim como sobre a eliminação de mercadorias (por exemplo, piores salários, benefícios e condições de trabalho). Custos de materiais (por exemplo, ingredientes menos dispendiosos em alimentos, às vezes com baixo valor nutricional) também podem ser minimizados. Tais reduções podem, por sua vez, levar a inúmeros comprometimentos à qualidade dos bens e serviços gerados pelos campos da tecnociência, que podem contribuir para muitos da- 
nos pessoais, sociais e ambientais. As exacerbações de tais comprometimentos parecem ter sido derivadas de decisões legais - por exemplo, em 1980, nos Estados Unidos da América (EUA) - permitindo contratos entre tecnocientistas e empresas/financiadores, que tenderam a mudar seus focos da geração de conhecimento, visando o bem-estar geral, para os interesses privados. (KRIMSKY, 2003; MIROWSKI, 2011)

Há numerosos exemplos, portanto, de comprometimentos para produtos ou serviços gerados com a ajuda de campos da tecnociência que estão ligados a vários danos pessoais, sociais e ambientais. Leonard (2010) sugere, por exemplo, que muitos produtos manufaturados contêm numerosas substâncias químicas não testadas e potencialmente perigosas. Da mesma forma, as empresas farmacêuticas, aparentemente, têm comprometido a qualidade do produto - como, por exemplo, por meio de testes de drogas com indivíduos jovens, que são menos propensos a experimentar efeitos colaterais negativos. (ANGELL, 2004) Em alguns casos de modo muito sério, algumas empresas são bem conhecidas por incentivar os engenheiros a projetar produtos para que eles falhem rapidamente - o que pode levar o consumidor a descartar as mercadorias danificadas e substituí-las pelas últimas inovações. (LEONARD, 2010) Consequentemente, os seres humanos e nossos ambientes vivos e não vivos são ameaçados por tais mercadorias comuns, como: cigarros (BARNES; HAMMOND; GLANTZ, 2006), agrotóxicos (HILEMAN, 1998), comida rápida e outros alimentos industrializados (WEBER, 2009), produtos de limpeza doméstica (VASIL, 2007), produtos petrolíferos e veículos movidos a petróleo (KLEIN, 2014) e produtos da biotecnologia. (KLEINMAN, 2003) À luz de tais problemas, que parecem originar-se, em parte, de associações "ciência-negócios", sancionadas por governos, parece claro que mais cidadãos precisam estar preparados para avaliar criticamente processos e produtos dos campos da ciência e da tecnologia e, onde eles percebam problemas, que possam desenvolver e implementar planos de ação para tentar criar um mundo melhor.

\section{STEPWISE para uma cidadania ativa}

Em 2006, a estrutura teórica do STEPWISE ${ }^{4}$ foi desenvolvida para encorajar e permitir, aos alunos, ações sociopolíticas autodirigidas para abordar os danos que eles identificam, associados aos campos da ciência e da tecnologia. Esta estrutura teórica organiza cinco domínios de ensino e de aprendizagem para indicar que eles coafetam uns aos outros (por exemplo, ensino de habilidades $\leftarrow \rightarrow$ educação CTSA); todos os domínios podem informar (e beneficiar-se de) ações sobre CTSA, dos estudantes - tais como petições, cartazes e/ou postagens em Twitter etc. para os políticos, empresas, cidadãos

4 STEPWISE é o acrônimo para Science \& Technology Education Promoting Wellbeing for Individuals, Societies \& Environments. Em português, Educação em Ciência \& Tecnologia promovendo o bem-estar de indivíduos, sociedades \& ambientes. Para aprender mais sobre esse framework para o ensino, a aprendizagem e a pesquisa e acessar recursos instrucionais relevantes, visite: www.stepwiser.ca. 
ativistas etc. Ações sobre problemas envolvendo relações CTSA estariam situadas no centro dessa estrutura teórica, indicando que os estudantes podem "consumir" algum do seu capital cultural (e social) (BOURDIEU, 1986), não apenas em si mesmos, mas também sobre os esforços "altruístas" para construir um mundo melhor.

Convencer os estudantes de que a educação que recebem pode ser usada também para ajudar outros seres vivos - incluindo ambientes - pode não ser fácil, particularmente em partes do mundo onde os cidadãos são fortemente encorajados e/ou precisam se concentrar no consumo de bens e serviços e, ainda, competem por empregos e status social. (BAUDRILLARD, 1998) Assim, um aspecto - chave do STEPWISE é encorajar e capacitar os estudantes a desenvolver a confiança, a experiência e a motivação para a pesquisa autodirigida (por exemplo, como estudos e experimentos) para aprender mais sobre as relações CTSA. Por ter maior controle das decisões sobre as conclusões de sua própria pesquisa, os estudantes podem desenvolver sentimentos de pertencimento mais profundos com relação a tais afirmações sobre questões envolvendo CTSA (WENGER, 1998) e podem, portanto, ser mais motivados a realizar ações para resolver os problemas que eles identificam. Por razões semelhantes, dar aos estudantes controle sobre as decisões acerca de como usar suas conclusões de pesquisa como base para as suas ações, mesmo que seja apenas parcialmente, pode dar-lhes fortes ligações a, e motivação para, tais ações. Com mais cidadãos preparados para avaliar criticamente as relações CTSA através da sua própria pesquisa, bem como para realizar ações, a fim de abordar os problemas que percebem neles, podemos evoluir para formas mais participativas de democracia - as quais, como já argumentamos acima, parecem necessárias, considerando que as pessoas e os grupos poderosos, nas sociedades, podem não estar fornecendo, eles mesmos, a liderança mais confiável. Estes aspectos do STEPWISE alinham-se com a recomendação de Levinson (2010) de que, para incentivar uma participação mais democrática, na qual os cidadãos monitoram e desafiam as fontes de poder, os estudantes devem engajar-se na práxis (prática crítica, reflexiva; como a pesquisa autodirigida) como parte da sua participação em situações de "dissidências e conflitos", tais como ações sociopolíticas sobre os problemas sociocientíficos.

Pouco depois de ter sido desenvolvida uma primeira versão da estrutura teórica do STEPWISE, professores em vários contextos escolares foram incentivados a usá-la como uma base para o ensino e a aprendizagem com os estudantes. Muito rapidamente se tornou evidente, no entanto, que eles perceberam a primeira versão como sendo muito complexa - preferindo um esquema mais sistemático, como aquele da Figura 2 (BENCZE; CARTER, 2011), que é um rearranjo de todos os domínios da versão original. Nesta abordagem, em geral, primeiro se apresenta, aos estudantes, um ou mais conjuntos (ciclos) de aulas e atividades de "aprendizagem mediada" para ajudá-los a ganhar experiência, confiança e motivação para, ao final, serem capazes de executar projetos de 
ação negociada e informada por pesquisa (RiNA) ${ }^{5}$ para abordar problemas de CTSA que eles próprios escolhem. O professor pode ou não optar por repetir (uma ou mais vezes) as três fases do ciclo de aprendizagem mediada, dependendo da idade e do nível de conforto dos estudantes e, de fato, o nível de conforto do professor com várias estratégias dentro do esquema (Figura 2).

Figura 2 - Estrutura pedagógica do modelo STEPWISE ${ }^{6}$

Este modelo é uma versão prática do quadro teórico STEPWISE (Educação em Ciência \& Tecnologia promovendo o bem-estar de Indivíduos, Sociedades e Ambientes;). Neste esquema, os estudantes são preparados com aulas e atividades de "aprendizagem por mediação", com suporte do professor, quando necessário, até que o professor sinta que os estudantes estão prontos para projetos de RiNA (ações negociadas e baseadas em pesquisa) autodirigidos para abordar problemas que eles identificam nas relações entre os campos CTSA.

Obviamente, não é suficiente que o professor ofereça exemplos, para que os estudantes entendam e sejam capazes de autodirigir projetos para RiNA, a fim de abordar problemas nas relações CTSA. Os estudantes frequentemente necessitam de prática; ainda que com algum suporte do professor, sempre que necessário. O professor pode, por exemplo, oferecer aos estudantes uma amostra de controvérsias CTSA, pedir a eles para conduzir uma pesquisa secundária (por exemplo, pesquisas na internet) e uma primária (por exemplo, estudos) para aprender mais sobre tais assuntos e tomar decisões sobre os problemas a abordar. Os estudantes poderiam, então, ser encorajados a projetar e colocar em prática planos de ação (por exemplo, pôsteres, petições, vídeos educacionais, apresentações, postagens online etc.) para abordar tais assuntos.
Uma vez que os estudantes frequentemente chegam nas aulas com Atitudes, Habilidades e Conhecimentos (ASK) prévios e os professores não estão conscientes de muitos deles, os professores podem estimular os estudantes a 'expressar' seus ASK em diferentes formas (por exemplo, discurso, desenhos, escrita). Aqui, os professores podem oferecer estímulos, como produtos e serviços típicos dos campos da ciência e da tecnologia (por exemplo, telefones celulares), e pedir que os estudantes expressem as relações CTSA associadas a tais produtos e serviços, além de problemas para o bem-estar de indivíduos, sociedades e ambientes (WISE), possíveis ações para abordar estes problemas e, por fim, a preparação (por exemplo, em termos de pesquisa) que eles precisam realizar para executar tais ações.

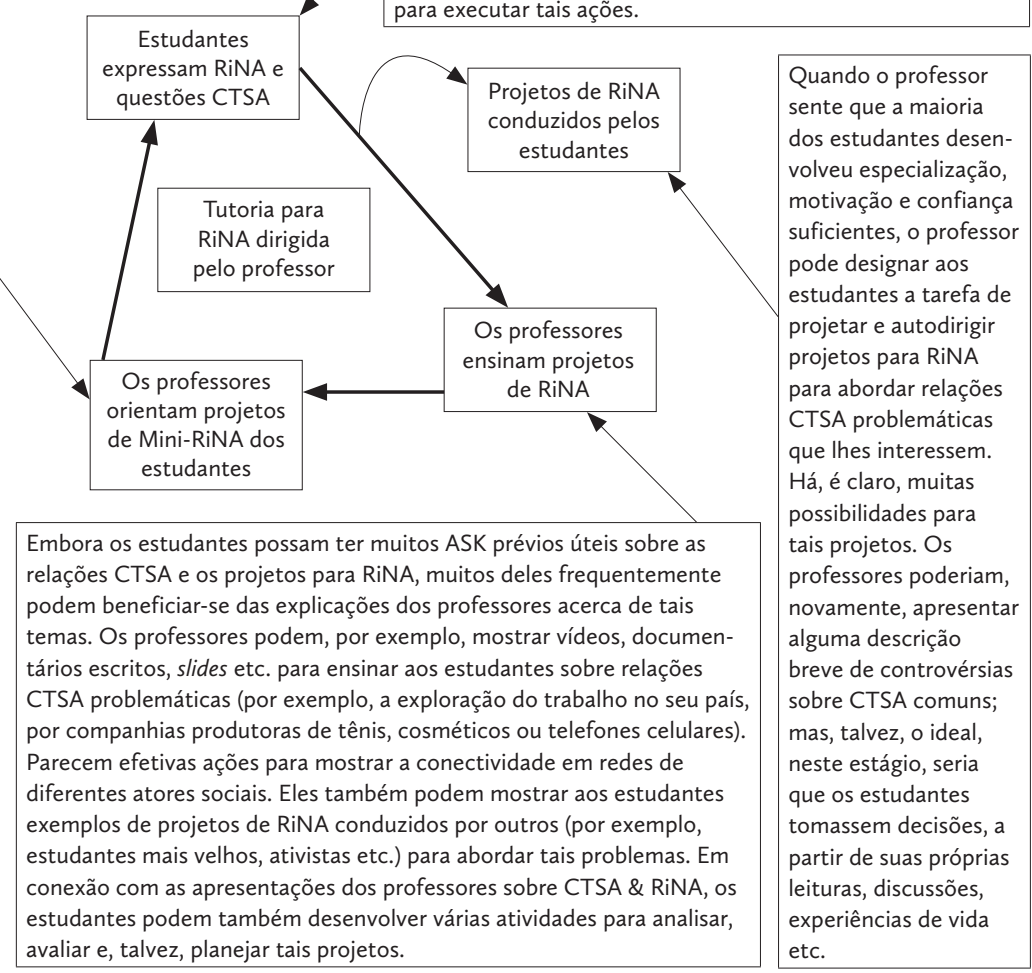

Fonte: elaborada pelos autores.

5 Ao longo do texto, utilizaremos a expressão RiNA, um acrônimo que se refere à expressão original, utilizada pelo autor, em inglês, Research-informed and Negotiated Action. (N. do T)

6 Ver em: <www.stepwiser.ca>. 


\section{Aprendizagem mediada: expresse, aprenda, aplique}

A aprendizagem mediada em três fases, ${ }^{7}$ representada na Figura 2, é baseada na teoria construtivista básica da aprendizagem (OSBORNE; WITTROCK, 1985), o que sugere que os aprendizes frequentemente têm Atitudes, Habilidades e Conhecimentos (ASK) que interagem com a informação recebida das situações de aprendizagem (por exemplo, comportamento observado de imãs) para formar, isto é, construir ASK, que são únicos para cada estudante ${ }^{8}$ e, criticamente, podem não coincidir com os do professor, dos cientistas ou de outros profissionais. Uma vez que as noções prévias dos estudantes sobre os fenômenos são muitas vezes subconscientes, práticas pedagógicas informadas pelo construtivismo, por vezes, envolvem o pedido para que os estudantes "expressem" (por exemplo, descrever em palavras, desenhos, modelos 3D etc.) os seus ASK pré-instrucionais. Assim, conforme detalhado abaixo, a aprendizagem mediada pode começar por pedir aos estudantes que expressem suas noções prévias sobre questões CTSA e projetos de RiNA. Dado que os estudantes muitas vezes podem se beneficiar de desenvolver outros ASK sobre estas (questões CTSA), então, o professor poderia conduzir aulas e atividades estudantis para "ensinar projetos de RiNA". Finalmente, uma vez que os estudantes estejam mais ligados a questões e ações, por serem dadas mais responsabilidades para as decisões sobre elas, o professor, então, envolveria os estudantes em projetos de mini-RiNA - com a orientação do docente, conforme necessário. No final de um destes ciclos, os estudantes podem ser conduzidos para a primeira fase do ciclo; isto é, para novamente "expressar questões CTSA e RiNA". Nesse ponto, o professor pode, então, julgar se deve ou não continuar com um segundo conjunto de aulas e atividades de aprendizagem mediada ou, como indicado na Figura 2, se deve envolver os estudantes em projetos de RiNA, conduzidos por eles mesmos.

\section{Aprendizagem mediada: estratégias de ensino e aprendizagem}

Para ajudar os educadores a implementar o esquema da Figura 2, algumas sugestões concretas são fornecidas abaixo para cada fase da aprendizagem - bem como alguns exemplos de projetos de RiNA, liderados por estudantes. No entanto, os professores, ao final, precisam ter mais controle sobre o desenvolvimento e a implementação de tais atividades pedagógicas - para não apenas abordar um repertório mais amplo de temas, mas também para desenvolver uma compreensão mais profunda sobre um determinado

7 As três fases, representadas na Figura 2, podem, não necessariamente, durar a mesma extensão de tempo; além disso, elas não devem ser consideradas completamente em separado. Pode haver sobreposições entre quaisquer duas fases, tais como ensinar aos estudantes sobre estratégias particulares de pesquisa, logo antes de que eles pratiquem.

8 O construtivismo social afirma que, a despeito da separação dos nossos cérebros, nós compartilhamos muitos ASK - através, por exemplo, dos usos comuns da linguagem. Logo, o grau em que nossas construções podem ser consideradas completamente únicas, de cada indivíduo, é questionável. 
tema, assim como certos compromissos com tais práticas de ensino e aprendizagem. A seguir, detalhamos alguns aspectos referentes às três fases.

\section{Estudantes expressam questões sobre CTSA e RiNA}

Resumidamente, esta fase destina-se a estimular os estudantes a "expressar" (por exemplo, dizer, desenhar, construir etc.) seus ASK pré-instrucionais sobre problemas relacionados a poder e/ou questões nas relações CTSA (consulte a Figura 1) e as ações que eles podem realizar para abordar os problemas de interesse para si mesmos (bem como as preparações que eles devem realizar antes de tais ações).

\section{Aspectos problemáticos da Ciência \& Tecnologia: atividades para expressar concepções prévias}

Antes de prosseguir com exemplos, pode ser útil, para os professores, pensar em uma versão mais reduzida das relações CTSA da Figura 1; isto é, algo como: $C \& T<[+/-] \rightarrow S \& A$.

Nessa concepção, reconhecemos que os campos da Ciência e da Tecnologia $(\mathrm{C} \& \mathrm{~T})$, muitas vezes, colaboram um com o outro. Como resultado, podemos imaginar os campos de C\&T sendo influenciados por e tendo efeitos positivos ou negativos sobre as Sociedades (e os indivíduos nelas) e os Ambientes (S\&A). Podemos, então, usar várias estratégias para conseguir que os estudantes expressem seus pontos de vista sobre tais relações. Os professores podem, por exemplo, "expor" os estudantes a vários aspectos de C\&T e pedir-lhes para avaliar os seus efeitos sobre o WISE e o que pode ser feito para resolver quaisquer problemas que eles identifiquem. Embora possa, por vezes, ser impraticável, por exemplo, levar os estudantes para lugares onde os cientistas e/ou engenheiros fazem os seus trabalhos, os professores podem conectar os estudantes com produtos dos trabalhos desses profissionais; por exemplo, leis, teorias e invenções ou inovações. Como as leis e teorias são relativamente abstratas, no entanto, talvez, possa ser melhor, em primeiro lugar, expor os estudantes a várias invenções ou inovações. De fato, como mencionado acima, a ênfase que se dá atualmente à $C \& T$ parece favorecer a geração de produtos e serviços inovadores para a venda (mercadorias). Conseguir que os estudantes interajam com mercadorias comuns poderia ser feito de uma forma relativamente personalizada, pedindo aos alunos para nomear, listar, trazer para a aula etc. produtos e serviços que eles e/ou membros da sua família compram/usam - como carros, bicicletas, telefones celulares, cosméticos, artigos de higiene, comida rápida e alimentos manufaturados etc. Isso poderia ser complementado com imagens ou outros meios de comunicação veiculando mercadorias (por exemplo, vídeos de pessoas a usá-los). Os estudantes poderiam, então, ser solicitados a avaliar tais produtos/serviços/mercadorias - em primeiro lugar, de forma muito ampla; por exemplo, perguntando: “O que é 'bom' e 'mau' com relação a estes __ [produtos/serviços] __?”. Depois de 
algum tempo, o professor poderia, então, fazer-lhes perguntas mais convergentes, como: "De que formas este __ [produto/serviço] __ poderia ser bom e/ou mau para WISE? Explique”, "Que indivíduos e/ou grupos são, provavelmente, os maiores responsáveis pelos problemas que você nota? Explique", "Explique o que você acha que precisa mudar sobre este __[produto/serviço]__ para que o mundo seja melhor?”, "Como você pode aprender mais sobre este __[produto/serviço]_- para tomar decisões sobre como ele deveria ser alterado?”. E "de que maneira você poderia encorajar as pessoas e/ou grupos poderosos para agir a fim de melhorar este __[produto/ serviço]__?”.

Talvez depois de focar na atenção dos estudantes sobre os produtos da C\&T, o professor possa voltar a atenção daqueles para os problemas comuns para WISE ligados aos campos da C\&T. Os estudantes podem, por exemplo, buscar, por si próprios, ou receber, dos professores, imagens de vários problemas que afetam WISE, tais como: águas poluídas; lixo em recipientes para reciclagem; taxas de câncer pelo fumo; trabalhadores pobres (que trabalham jornadas longas), produzindo mecardorias manufaturadas para pessoas ricas; imagens de ensaios brutais em animais (com as devidas advertências); etc. Com o tempo, o professor pode prosseguir com o pedido de que os estudantes avaliem as ações que poderiam ser tomadas para abordar os problemas aparentes. Estas ações poderiam incluir questões sobre vários atores sociais (stakeholders) relacionados à mercadoria; tais como: "Os governos devem definir leis mais fortes para controlar o que as empresas de alimentos podem colocar em comidas rápidas e manufaturadas?", "Adolescentes maiores de 16 anos devem poder fumar cigarros sem o consentimento de seus pais/responsáveis?" e "Os adolescentes devem escrever cartas aos gerentes/administradores/gestores de cinemas, pedindo que removam anúncios violentos e sensuais?”.

\section{A natureza das atividades de aprendizagem mediada: modelo do controle de aprendizagem}

No geral, no planejamento e na análise/avaliação das atividades para esta fase da aprendizagem mediada (e as outras fases e projetos dos estudantes), o esquema da Figura 3 tem sido útil. (LOCK, 1990) Ele é composto de dois eixos contínuos, que se cruzam, para julgar a natureza e a extensão do controle da aprendizagem do estudante. No eixo horizontal, as escolhas dos tópicos e métodos podem ser totalmente dirigidas pelo professor (TD, de Teacher-Directed) ou totalmente dirigidas pelo estudante (SD, de Student-Directed) ou alguma combinação dos dois. O contínuo no eixo vertical, por sua vez, permite rastrear as conclusões a partir das atividades - desde o tipo fechado (CE, de Closed-Ended), o que significa que há apenas uma conclusão pré-determinada (normalmente definida pelos professores e livros), até de tipo fim-aberto (OE, de Open-Ended), nas quais há muitas conclusões possíveis (geralmente determinadas por julgamentos dos estudantes, com base em evidências e teorias disponíveis). Para a 
primeira fase (os estudantes expressam as questões CTSA \& RiNA) da aprendizagem mediada, na Figura 2, parece que muitas atividades devem ser principalmente SD/OE. Claramente, no entanto, para estimular os estudantes a reagirem a fenômenos (por exemplo, imagens de mercadorias), deve haver algum direcionamento do professor e, sem dúvida, as conclusões dos estudantes podem não ser totalmente abertas (por exemplo, por causa das decisões dos professores sobre os estímulos a oferecer). Mas, se essas atividades são sobre estudantes expressando suas próprias noções prévias, as atividades devem ser primariamente SD/OE. Assim, quando os professores avaliarem as respostas dos estudantes às suas instruções ou perguntas nesta fase, parece que, principalmente, deve ser dado a eles o crédito pelos esforços legítimos que eles demonstram em suas respostas - ao invés de ter respostas "corretas" (o que seria tornar as questões de fim fechado, CE).

Figura 3 - Modelo do controle de aprendizagem

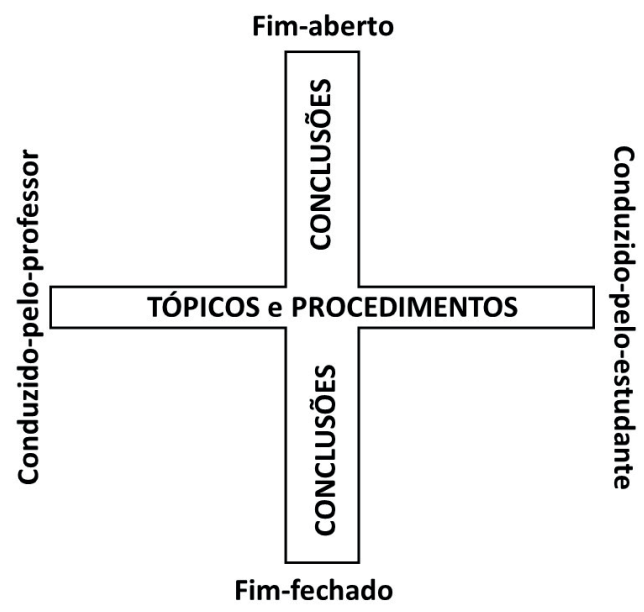

Fonte: Bencze (2018).

\section{Os professores ensinam projetos de RiNA}

Embora a primeira fase da aprendizagem mediada, na Figura 2, possa ajudar o professor e os estudantes a se tornarem mais conscientes das noções prévias dos estudantes sobre as relações CTSA e possíveis problemas e ações, os estudantes ainda podem se beneficiar de ter o professor ensinando alguns problemas relacionados com questões de poder, nas relações CTSA específicas, e sobre projetos de RiNA eficazes realizados por outros para enfrentar tais problemas. Tal ensino não se destina a substituir noções prévias dos estudantes, que devem ser dignificadas, mas destina-se a expandir os repertórios deles. Para garantir que os estudantes desenvolvam, pelo menos, uma compreensão dos ASK específicos pretendidos pelo professor, aulas e atividades devem ser relativa- 
mente dirigidas pelo professor (TD) e com fim fechado (CE), em termos de conclusões sobre as relações CTSA e abordagens de RiNA.

Normalmente, os professores vão ensinar os estudantes sobre questões, pesquisas e ações relacionadas a CTSA, no contexto do tema "produtos" (por exemplo, leis e teorias) da C\&T para unidades particulares em estudo - como aquelas sobre biologia celular, circuitos elétricos ou reações químicas. Ensinar sobre RiNA e CTSA não deve, contudo, ser utilizado como base para os estudantes "descobrirem" produtos da C\&T. Frequentemente, os estudantes (particularmente os mais desfavorecidos) possuem limitações em relação a tais descobertas. Assim, para que o conhecimento de tais produtos não seja um fator limitante na educação envolvendo RiNA e CTSA, o ensino sobre esses produtos deve ocorrer separadamente, embora em paralelo, ao ensino de RiNA e CTSA.

\section{Atividades para ensinar sobre RiNA e CTSA: casos e métodos de estudo de caso}

Entre as abordagens para ensinar RiNA sobre CTSA, é muito popular o uso de "casos" e "métodos de estudo de caso" - com o primeiro sendo um documentário das relações CTSA e/ou projeto de RiNA relevantes e o último sendo um conjunto de instruções e/ou perguntas para engajar os estudantes em interações com os casos, a fim de alcançar resultados de aprendizagem desejados. Para esta segunda fase da aprendizagem media$\mathrm{da}$, aulas e atividades devem proporcionar aos estudantes oportunidades para desenvolver compreensão e atitudes sobre:

- $\quad$ problemas ligados a questões de poder nas relações CTSA;

- métodos de divulgação de pesquisa primária e secundária; e

- ações sociopolíticas para abordar problemas de CTSA identificados.

$\mathrm{Na}$ terceira fase da aprendizagem mediada (ver abaixo), aos estudantes será dado maior controle sobre as decisões acerca destes três componentes, de modo que os estudantes possam aprofundar os seus ASK sobre eles.

Os casos de CTSA aparecem em vários formatos ou meios (media formats). Casos tradicionais "baseados em texto", com textos "estáticos” e imagens, ainda são muito usados. Eles costumam fornecer alguns detalhes (por exemplo, dados e invenções) sobre C\&T, relacionando-se a um fenômeno e a correspondentes relações sociais e ambientais. Muitas vezes, problemas, em tais relações, são identificados nos casos, e também são descritas indicações de ações, incluindo a preparação, como a pesquisa primária e secundária, que pessoas e/ou grupos têm realizado para abordar esses problemas. Um exemplo disso é o caso exposto no Apêndice A sobre os, assim chamados, "diamantes de sangue"; isto é, diamantes extraídos às custas de vidas e bem-estar de muitos trabalhadores pobres. Os professores podem usá-lo, por exemplo, em coordenação com o ensino sobre o elemento carbono. 
Em muitos contextos, é muito comum o uso de casos multimídia e métodos de estudo de caso para a educação CTSA. Se um professor está ensinando sobre biologia, por exemplo, uma excelente fonte de casos é a Action Bioscience. ${ }^{9}$ Há, no entanto, muitos outros sites na internet, e os professores podem encontrar muitos através de pesquisas no YouTube. Enquanto mostrar aos estudantes vídeos de questões e ações desenvolvidas por adultos pode ser útil, os estudantes podem ser particularmente atraídos por aquelas iniciativas produzidas por outros estudantes de idades similares. Por exemplo, após um professor ter mostrado aos estudantes vídeos de discursos feitos pela Royal Society for the Arts (RSA), ${ }^{10}$ em que o áudio está sincronizado com animações relevantes, os estudantes criaram um vídeo semelhante ${ }^{11}$ sobre os efeitos das mudanças climáticas relacionadas a automóveis movidos a combustíveis fósseis em comparação com outros modos de transporte. Além de sua natureza criativa, este vídeo poderia ser usado para ensinar sobre todos os três objetivos (acima) da segunda fase da aprendizagem mediada. Em termos de relações CTSA problemáticas, por exemplo, os estudantes claramente enfatizaram os problemas ambientais (por exemplo, mudança climática) derivados de produtos da tecnologia (por exemplo, carros). Eles também ilustram consideráveis pesquisas secundárias (por exemplo, as estatísticas sobre o uso do carro nos EUA) e primárias (por exemplo, opções de transporte para a escola de meninas versus de meninos). As escolhas de ações deles incluem modos ecologicamente mais sustentáveis, incluindo o uso de bicicletas e transporte público. Apesar de não ser crucial, no entanto, o professor pode apontar para os estudantes que eles poderiam ter feito mais referências a questões de poder, na produção do vídeo, tais como a (des)regulamentação governamental das indústrias de automóveis que favorecem os veículos movidos a petróleo. O professor pode, assim, apontar outras formas de ação que os estudantes poderiam usar - tais como: fazer lobby para pessoas influentes (power-brokers) (por exemplo, petições e cartas aos governos e empresas de automóveis), educação das comunidades (por exemplo, campanhas online) e engenharia de formas de transporte mais sustentáveis (por exemplo, cadeiras de rodas eficientes, movidas a pessoas, talvez com volantes e engrenagens eficientes).

Como observado acima, para garantir que os estudantes obtenham concepções dos três objetivos desta fase da aprendizagem mediada, nós recomendamos que os professores mantenham um controle considerável da aprendizagem. Dito isto, a motivação dos estudantes para essa aprendizagem, muitas vezes, refere-se à proporção em que eles são autorizados a tomar decisões relevantes. Assim, parece louvável oferecer aos estudantes instruções e perguntas para que se engajem de modos mais pessoais com os casos. Alguns destes podem focar, é claro, a compreensão, enquanto

\footnotetext{
9 Ver em: <http://actionbioscience.org>.

10 Ver em: <https://www.thersa.org/discover/videos/rsa-animate/>.

11 Ver em: <https://www.youtube.com/watch?v=cfD-_p-2ux0>.
} 
outros podem encorajar os estudantes a analisar situações desconhecidas, propor alternativas e avaliar alegações. Para os três desdobramentos acima, algumas instruções e perguntas podem incluir:

- $\quad$ problemas nas relações CTSA ligadas a questões de poder: "resumidamente, explique como os diamantes são formados"; "explique por que alguns diamantes podem ser considerados sangrentos"; e "usando setas, mostre uma sequência de pessoas envolvidas com diamantes do "começo ao fim";

- pesquisas primária e secundária e métodos de divulgação: “com base neste caso, como podem os pesquisadores aprender sobre a violência relacionada à mineração de diamantes?", "liste dois fatos sobre as mudanças climáticas que os estudantes provavelmente determinariam por meio de pesquisa secundária” e "para saber sobre o conhecimento dos seus colegas acerca dos problemas com a mineração de diamantes, apresente um par de variáveis que você poderia monitorar em um 'estudo correlacional' (comparação de possíveis efeitos de uma variável que está naturalmente mudando com outra variável)”; e

- Ações Sociopolíticas para abordar problemas CTSA percebidos: "deveriam os governos rotular cuidadosamente diamantes que foram extraídos em áreas em conflito?"; e "deveriam os governos tornar a mineração de diamantes ilegal, obrigando as empresas a substituí-los por diamantes sintéticos?”.

\section{Expandindo a educação CTSA para RiNA: usando a Teoria Ator-Rede}

Talvez porque educadores em ciência podem não querer mostrar uma imagem negativa da CT, um problema comum com casos de RiNA e CTSA é que eles podem não fazer referências adequadas a certas entidades potencialmente embaraçosas - como corporações que podem ter reduzido os custos para aumentar os lucros. Desta perspectiva, Pierce (2013) recomendou que os educadores em ciência ensinem os estudantes sobre Teoria Ator-Rede (TAR) (LATOUR, 2005) e, consequentemente, construam mapas de ator-rede para representar as relações CTSA (e, presumivelmente, projetos de RiNA). A TAR propõe que todas as entidades (actantes) fazem parte de múltiplas relações recíprocas envolvendo entidades simbólicas, assim como entidades vivas e não vivas. As relações CTSA podem, portanto, consistir em actantes humanos não normalmente descritos nos contextos tradicionais de educação científica - como organizações econômicas transnacionais, incluindo, por exemplo, as corporações transnacionais, o Banco Mundial, o Fundo Monetário Internacional, a Organização Mundial do Comércio e a Organização para a Cooperação e o Desenvolvimento Econômico. Enquanto isso, entidades/actantes não-humanos, que podem ser incluídos em redes, podem consistir em: softwares e equipamentos de computadores utilizados em laboratórios de ciência; objetos de estudo (por exemplo, peixes, moléculas, quarks); acordos de comércio transnacional (por exemplo, Acordo de Livre Comércio da América do Norte); e, em particular, 
no caso de anúncios, actantes simbólicos idealizados, como "legal", "picante" e "sexy", associados a mercadorias como perfumes, carros e roupas.

Apesar de que pode ser mais democrático ajudar os estudantes a aprender sobre a TAR, construir mapas ator-rede não é fácil - por causa, por exemplo, da sua natureza complexa, incerta e dinâmica. Uma série de apresentações, discussões e atividades estudantis sobre TAR é, portanto, provavelmente necessária. Uma técnica comum é nomear uma mercadoria muitas vezes utilizada pelos estudantes, tais como um telefone celular, para conduzir uma aula socrática com eles - em que o professor e os estudantes constroem um mapa simples da rede que representa actantes simbólicos vivos e não vivos conectados à mercadoria. Em associação com tal instrução, os estudantes poderão ser convidados a assistir o vídeo A História das Coisas (The Story of Stuff), ${ }^{12}$ seguir algumas instruções do professor e responder a perguntas feitas pelo professor e por eles. Para complementar este trabalho, um excelente conceito para ensinar aos estudantes é o de como mercadorias, muitas vezes, são como um "cavalo de Tróia"; isto é, enquanto os consumidores se concentram em actantes simbólicos positivos - tais como "sexy", "poderoso" e "inteligente" - que podem ser evidentes "por fora" das mercadorias, eles podem estar distraídos e não perceber actantes nocivos "no interior" (por exemplo, produtos químicos tóxicos, substâncias que causam dependência e subprodutos poluentes). Depois de tal instrução e de uma pesquisa secundária relacionada, três estudantes do $1^{\circ}$ ano do ensino médio, de um curso de ciência preparatório para a universidade, desenvolveram o mapa ator-rede, reproduzido na Figura 4. Tendo aprendido sobre problemas com spray de cabelo comercial, os estudantes, em seguida, conduziram uma pesquisa primária - na forma de pesquisas acerca dos conhecimentos e usos de sprays de cabelo pelos colegas. Baseados em seus resultados de pesquisa e, provavelmente, nos seus ASK prévios sobre sprays de cabelo, eles, então, desenvolveram e testaram uma fórmula caseira de spray de cabelo que eles consideraram segura e ambientalmente saudável. Para promover esta ação, então, eles anunciaram seu produto, usando cartazes, como o mostrado na Figura 5. Estas ações tiveram alguns elementos da TAR, no sentido de que um cartaz foi combinado com informação, com uma invenção e com fotos de sujeitos testados.

12 Ver em: <http://storyofstuff.org/movies/story-of-stuff/> e <https://www.youtube.com/watch?$v=7 q F i G M S n N j w>$. 
Figura 4 - Um mapa ator-rede dos estudantes sobre o spray de cabelo

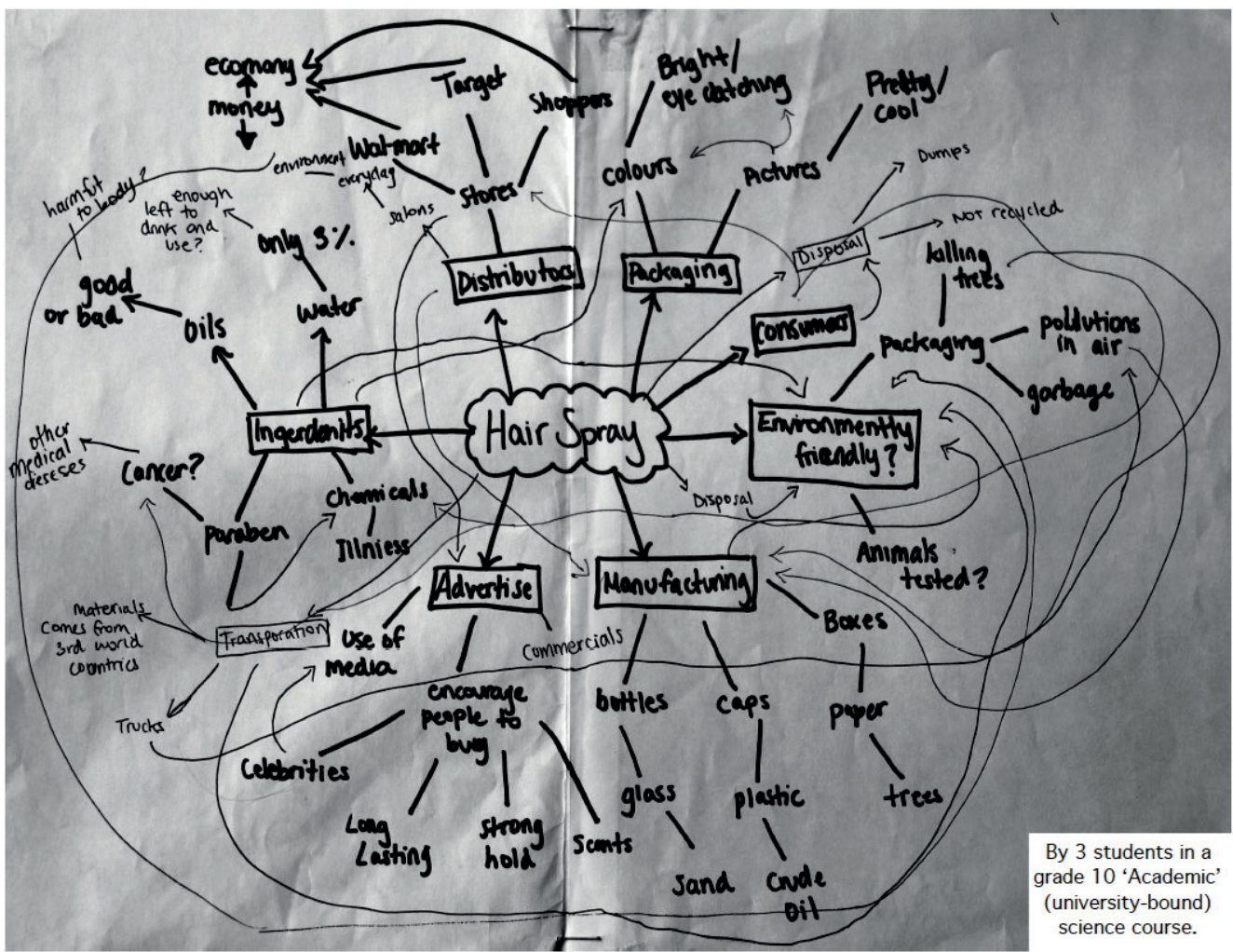

Fonte: Bencze e Krstovic (2017, p. 242). 
Figura 5 - Ações dos estudantes sobre o spray de cabelo

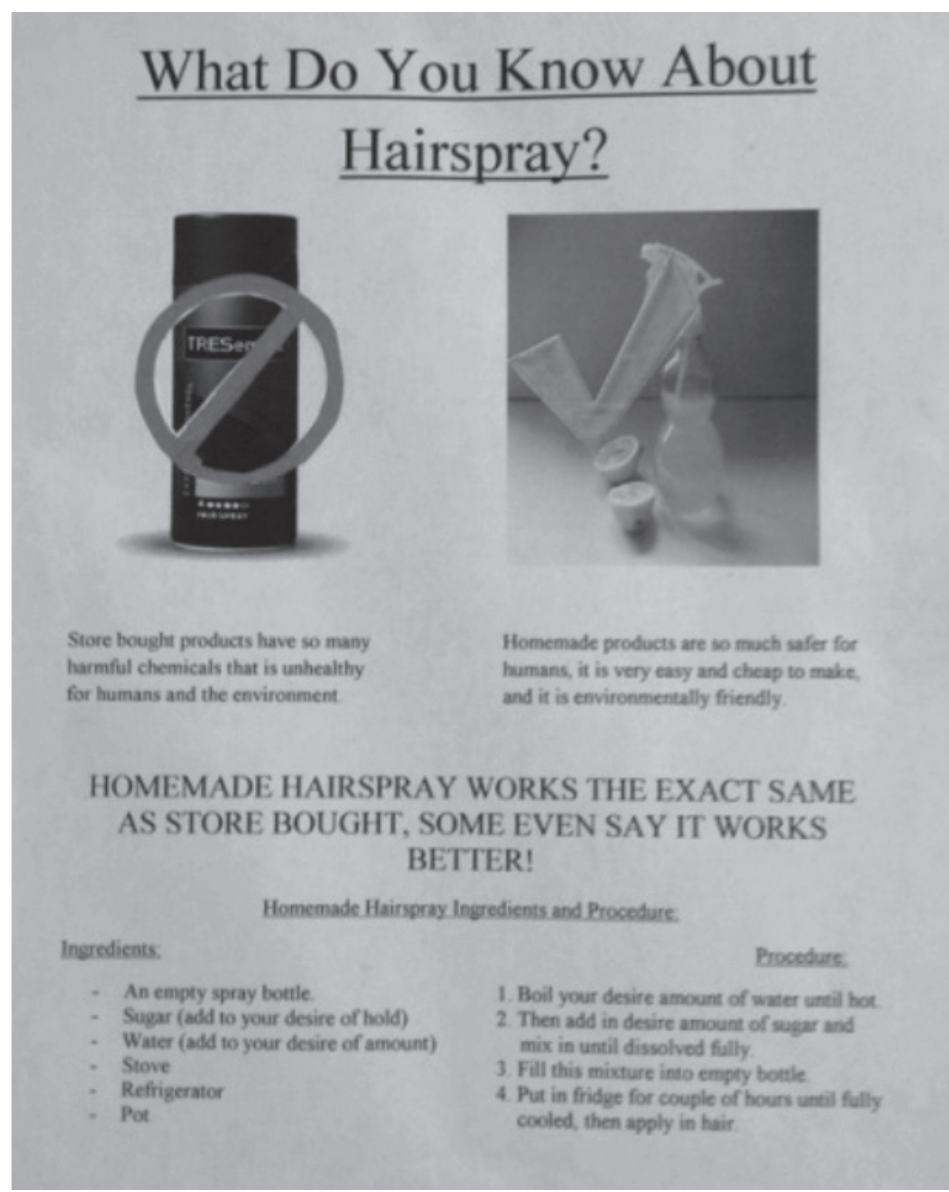

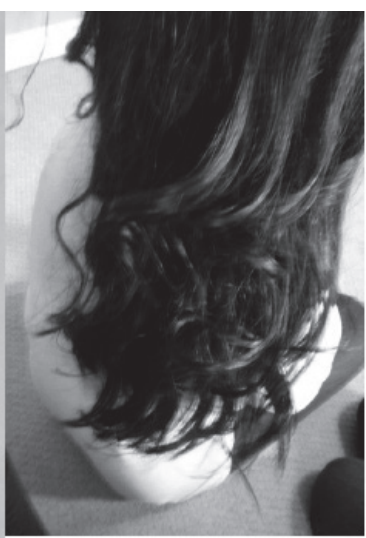

Commercial Hairspray

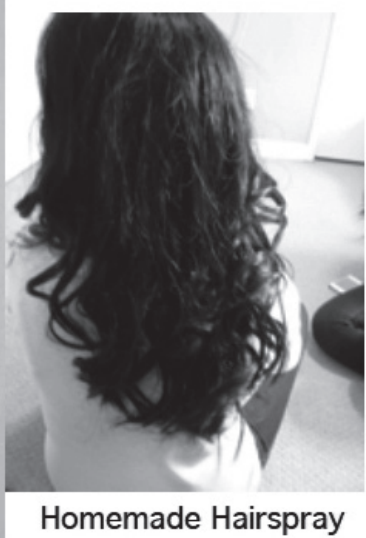

Fonte: elaborada pelos autores.

Através do ensino e da aprendizagem associados às sugestões acima, os estudantes podem desenvolver novas concepções de relações entre CTSA decorrentes do exame dos actantes poderosos (por exemplo, corporações transnacionais com o apoio do governo) e de ações baseadas em pesquisa realizadas por grupos de pessoas, para abordar os problemas de CTSA. É improvável, contudo, que os ASK deles a este respeito sejam totalmente alterados ou formados após essas aulas e atividades. Isso pode exigir oportunidades, como as descritas na próxima subseção, para que eles se engajem em projetos de RiNA facilitados pelo professor, para abordar questões de CTSA de sua própria escolha (e, mais tarde, projetos liderados por estudantes deste tipo). 


\section{Ensinando Natureza da Ciência: o Perfil da Teoria Científica}

Antes da próxima fase desta aprendizagem mediada, os educadores podem querer ajudar os estudantes a desenvolverem as suas concepções sobre a $\mathrm{NdC}$ (e, em certa medida, sobre a natureza da tecnologia também). As escolas tendem a promover crenças em métodos científicos relativamente lógicos e imparciais que levam a conclusões, relativamente certas, sobre o mundo - pontos de vista não bem suportados por estudos em história, filosofia e sociologia da ciência. (HODSON, 2008) É conveniente pensar em tais pontos de vista em termos do Perfil da Teoria Científica (STP, do inglês, Scientific Theory Profile), de Loving (1991), representado na Figura 6. Como o quadro da Figura 3, o STP é constituído por dois eixos contínuos em interseção; neste caso, para representar diferentes visões sobre a $\mathrm{NdC}$. O eixo horizontal diz respeito aos pontos de vista sobre o quanto os cientistas usam lógica "pura" para fazer julgamentos sobre as teorias (muitas vezes relevantes para os dados). Em um extremo, os "racionalistas" alegam que os cientistas baseiam estritamente seus julgamentos na lógica, na razão e no pensamento sistemático. No outro extremo, os "naturalistas" alegam que, além de lógica etc., os cientistas não podem deixar de ser influenciados por uma série de fatores psicológicos e sociológicos - como gênero, humor, desejo e, em termos de perspectivas mais abrangentes, de cultura, política, economia etc. Enquanto isso, as posições sobre o "valor de verdade" das alegações dos cientistas são consideradas no eixo vertical. Os "realistas" afirmam que as alegações dos cientistas (por exemplo, leis e teorias) podem corresponder às entidades em estudo; enquanto "antirrealistas" acreditam que as alegações dos cientistas não podem corresponder a fenômenos do mundo, muito embora possam construir aproximações que podem ter o apoio de um grupo de colegas. Tais pontos de vista sobre a ciência podem ser úteis na consideração de relações entre CTSA e ações subsequentes para abordar os problemas percebidos. Embora haja muitos aspectos da $\mathrm{NdC}$ a serem considerados usando o STP, as relações entre financiadores, corporações e cientistas (e engenheiros) e suas respectivas instituições podem ser de interesse particular para a educação CTSA. Parece claro que os indivíduos (incluindo estudantes) que ocupam posições racionalistas-realistas sobre a ciência não apoiarão, tão provavelmente quanto os naturalistas-antirrealistas, as alegações de que os cientistas muitas vezes são significativamente influenciados pelo setor privado e que, além disso, muitas dessas influências podem comprometer a integridade dos campos da C\&T, que muitas vezes resultam em danos ao bem-estar dos indivíduos, sociedades e ambientes. (KRIMSKY, 2003; MIROWSKI, 2011)

Dependendo das posições dos educadores sobre o STP, eles podem ajudar os estudantes a entender as posições naturalistas-antirrealistas - que, novamente, podem 
levar os estudantes a aceitar a existência dos problemas resultantes de parcerias entre ciência e negócios. Embora existam várias abordagens à educação para NdC, talvez os estudantes possam se beneficiar da estratégia chamada Imersão Dialética Indutivo-Dedutiva (IDDI, do inglês Inductive-Deductive Dialectic Immersion). (BENCZE; ELSHOF, 2004) Isso pode ser pensado como uma abordagem construtivista aplicada, em que os estudantes exploram (indutivamente) suas noções prévias sobre NdC; nós, professores, ensinamos algumas perspectivas sobre $\mathrm{NdC}$; e, em seguida, eles têm oportunidades para avaliar (dedutivamente) - e, talvez, descobrir novas perspectivas sobre NdC, através de investigações científicas realistas e atividades de aplicação. Isso pode começar, por exemplo, por envolver os estudantes no "jogo de troca de cartões", no qual eles:

- posicionam-se sobre seis declarações sobre NdC (em cartões separados) em termos daqueles mais alinhados com as suas opiniões sobre a ciência;

- tentam trocar com colegas os cartões que contêm declarações com as quais concordam menos (recebendo, em troca, cartões com declarações, com as quais estão mais de acordo); e

- reúnem-se com os colegas que sustentam opiniões semelhantes para escrever uma declaração geral sobre NdC. (COBERN; LOVING, 1998)

Eles podem (ou não) concluir, por exemplo, que declarações como as seguintes se alinham com pontos de vista naturalistas-antirrealistas:

- o financiamento influencia a direção da ciência em virtude das decisões que são tomadas sobre que pesquisa apoiar;

- o empreendimento científico está situado em contextos históricos, políticos, culturais e sociais específicos; assim, questões, métodos e resultados científicos variam de acordo com o tempo, o lugar e o propósito da pesquisa; e

- cientistas de um grupo de pesquisa tendem a ver as coisas de modo similar, de modo que até mesmo grupos de cientistas podem ter problemas para ser inteiramente objetivos.

Na sequência, ao ensinar aos estudantes sobre vários casos envolvendo CTSA, os professores podem, então, apontar exemplos em que diferentes comportamentos dos cientistas (e, talvez, de engenheiros, também) se alinham com as diferentes posições sobre o STP. Posteriormente, quando engajados em diferentes projetos de RiNA, que lidam com relações CTSA específicas, os professores podem, então, encorajar os estudantes a reconsiderarem seus pontos de vista sobre NdC relevantes para o STP. 
Figura 6 - Perfil da Teoria Científica

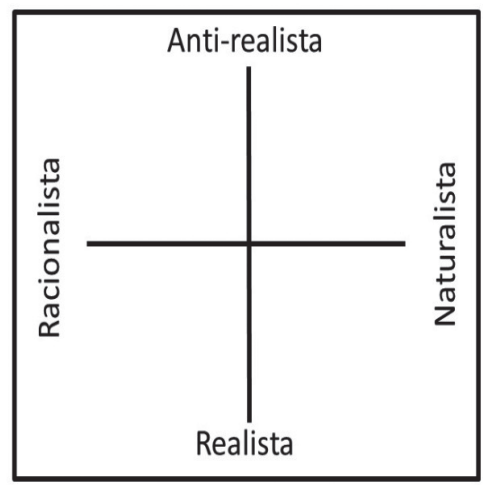

Fonte: Bencze, Bowen, Alsop (2006, p. 406), com base em Loving (1991).

\section{Os professores orientam os projetos mini-RiNA dos estudantes}

Aulas e atividades descritas na subseção acima tendem a ser relativamente mais TD/ CE. Os estudantes precisam, no entanto, de oportunidades para assumir mais controle sobre as decisões acerca das relações CTSA e projetos de RiNA, a fim de desenvolver uma maior compreensão acerca deles, assim como um comprometimento mais profundo para com eles. Assim, nesta terceira fase da aprendizagem, o professor pode pedir aos estudantes para desenvolver e implementar um projeto de RiNA em pequena escala a fim de abordar uma questão de CTSA de seu interesse, fornecendo orientação sempre que necessário. Dependendo da idade e dos estágios dos ASK dos estudantes com relação a RiNA sobre CTSA, os professores podem variar o grau do seu apoio a decisões relevantes dos estudantes. Em outras palavras, em termos do framework da Figura 3, as atividades abaixo podem ocorrer em algum lugar no meio de cada contínuo - embora, para alguns estudantes, sob algumas condições, os professores possam permitir mais controle por parte deles mesmos (SD/OE).

\section{Atividades para a escolha de questões sobre CTSA: pensando sobre mercadorias}

Os estudantes que necessitam de pouca orientação podem ser capazes de autodeterminar seus problemas e questões sobre CTSA, desenvolver métodos adequados de pesquisa e, em seguida, desenvolver e implementar ações adequadas com base nos resultados encontrados. A maioria dos estudantes, no entanto, parece exigir, pelo menos, uma lista de possíveis controvérsias - especialmente se esta é a primeira vez que eles passam por uma aprendizagem mediada. Os estudantes podem, por exemplo, ser ca- 
pazes de ter uma ideia geral sobre o assunto, a partir do conjunto de tecnologias e/ou ações da primeira fase da aprendizagem mediada, descrita acima. Os professores também podem ser capazes de desenvolver listas de problemas para determinadas áreas de conteúdo. Estas poderiam ser questões tão simples quanto "Até que ponto deveria ser permitida a extração de petróleo e gás nas regiões polares?”, "O que deveria ser feito para minimizar influências das corporações sobre escolha dos temas, sobre os métodos, resultados e divulgação dos resultados da ciência e da tecnologia?" ou "Até que ponto os governos deveriam investir o dinheiro na exploração do espaço?”. Ou, ainda, os professores podem desenvolver descrições de pequenos casos ou controvérsias, tais como estes:

- bebidas energéticas: as bebidas energéticas, que contêm altos níveis de cafeína, açúcares e sabores, são projetadas para melhorar o estado de alerta e aumentar o desempenho cognitivo. O consumo excessivo, no entanto, pode levar a efeitos colaterais negativos, incluindo insônia, irritabilidade, ansiedade, arritmia e dores de estômago. Além disso, há controvérsias nos nomes e slogans de diferentes bebidas voltadas aos adolescentes (por exemplo, Rockstar, Monster, Big Buzz, Cocaine). Grupos de pais estão se mobilizando para proibir a venda de bebidas energéticas para menores; e

- rótulos de alimentos para lanches (snacks): como os consumidores estão cada vez mais conscientes da sua saúde, muitas empresas estão tentando fazer com que seus produtos pareçam mais nutritivos, incluindo frases como: grãos integrais, baixo teor de gordura, feito com fruta natural e orgânico em seus pacotes. Um olhar mais atento para os ingredientes e as informações nutricionais revela que muitos desses produtos não são tão saudáveis como eles possam parecer.

\section{Atividades para escolher questões CTSA: Documentários Multiactantes}

Uma abordagem muito mais detalhada, mas que ainda exige que os estudantes aprendam mais através da pesquisa, está em apresentar aos estudantes Documentários Multiactantes (MAD, do inglês Multi-Actant Documentaries), como um tipo de caso, e fornecer-lhes métodos de estudo de casos que requerem que eles realizem uma pesquisa e, finalmente, ações para abordar os problemas que lhes interessam. Como descrito acima, é evidente que os interesses do setor privado muitas vezes impedem que os cidadãos se concentrem em certos actantes potencialmente problemáticos - como corporações transnacionais e acordos comerciais transnacionais. Para proporcionar aos estudantes representações mais realistas de contextos de CTSA, portanto, nós preparamos MAD para várias mercadorias. Usando a ferramenta online, Prezi, nossos MAD oferecem curtos documentários multimídia para alguns actantes simbólicos vivos e não vivos - um 
dos quais é ilustrado, na Figura 7, para comida rápida e alimentos manufaturados. ${ }^{13}$ Fundamentalmente, nós temos propositalmente omitido linhas entre os actantes que poderiam sugerir relações entre eles; e, assim, recomendamos aos professores que peçam aos seus estudantes para estudar actantes individuais em qualquer ordem e por períodos de tempo que lhes interessem. Nós sentimos que isso vai dar aos estudantes uma maior possibilidade de escolha e maior motivação para o desenvolvimento de ações para controvérsias e/ou problemas que eles identifiquem.

Figura 7 - MAD: alimentos rápidos e manufaturados

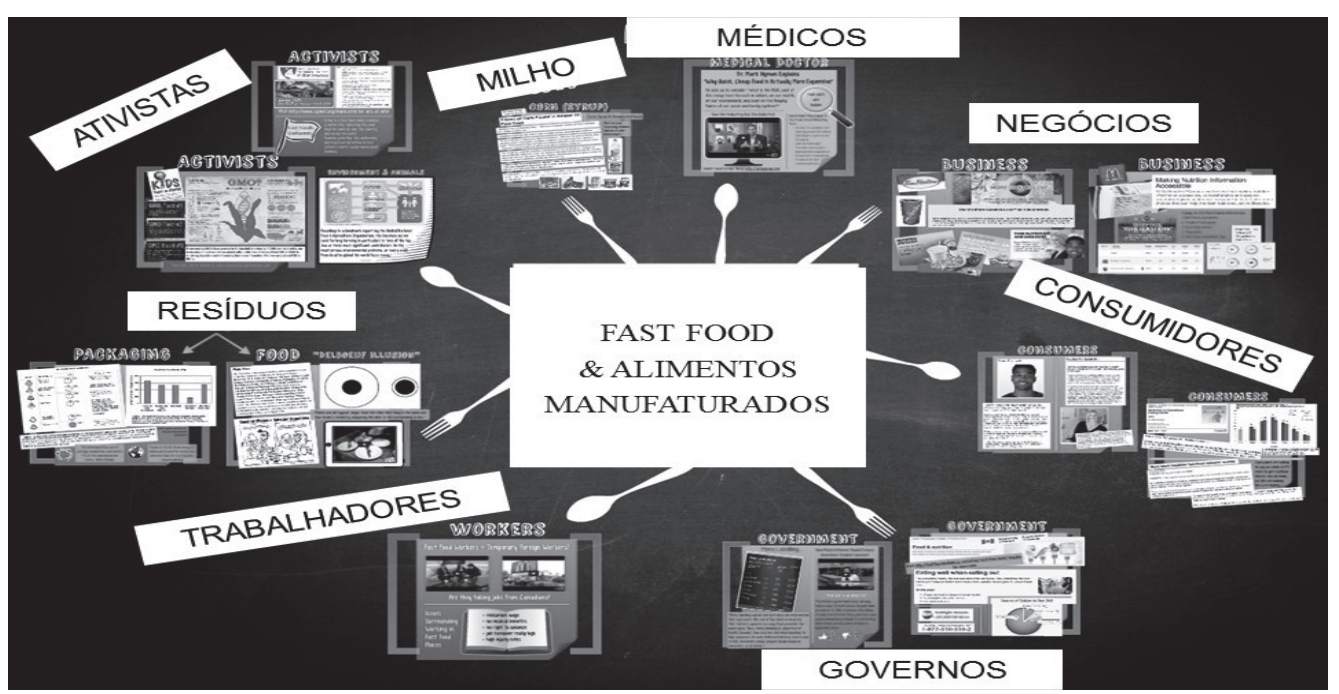

Fonte: elaborada pelos autores.

\section{Apoiando habilidades para RiNA sobre CTSA: experimentos e estudos}

Uma vez que os estudantes tenham questões CTSA para explorar, a partir dos recursos como aqueles acima, eles, então, poderiam começar a planejar e implementar pesquisas para saber mais sobre estas questões CTSA e determinar problemas particulares para resolver. Tendo aprendido mais sobre a questão, eles, então, conduziriam a sua própria pesquisa e, finalmente, usariam as suas descobertas para informar as decisões sobre ações para desenvolver e implementar. Para orientar os estudantes em tais projetos para RiNA, os professores podem usar um formulário de planejamento e avaliação, como aquele apresentado no Quadro 1. Como já indicado, o grau de orientação, em tais formulários e nas interações entre o professor e os estudantes que estão trabalhando em projetos de RiNA, dependerá das idades dos estudantes e dos estágios de familiaridade e conforto com ASK dentro destas aprendizagens mediadas dos estudantes.

13 Ver em: <https://prezi.com/th-fzepweg8w/fast-manufactured-foods/>. 
Um aspecto da ciência e/ou tecnologia frequentemente não abordado nas escolas, mas que muitas vezes é uma limitação em projetos de RiNA, dos estudantes, é a experiência, a confiança e a motivação para atividades de pesquisa e divulgação (e ação) autodirigidas. Assim, muitas vezes, é necessário proporcionar aos estudantes aulas e atividades de aprendizagem mediada a este respeito - especialmente no início de suas experiências com STEPWISE. A primeira consideração, ao longo destas linhas, no entanto, é determinar o que ensinar; incluindo decisões sobre quais habilidades, estratégias etc. cientistas normalmente usam em investigações científicas e atividades de divulgação. Gott e Duggan (2003) sugeriram, por exemplo, que os cientistas podem usar vários "conceitos de evidência", tais como controle de variáveis, duplicação de testes e erro instrumental (versus erro humano), em muitas investigações científicas. Estas são, às vezes, colocadas em sequências, como aquelas representadas na Figura 8. Tais listas e sequências devem ser usadas com cautela, no entanto, uma vez que estudos de cientistas em ação sugerem que eles podem nem sempre usar todas essas habilidades, estratégias etc., ou utilizá-los em sequências específicas, dependendo de vários fatores. Por conseguinte, parece melhor ensiná-los no contexto da investigação científica como um todo e/ou de projetos de desenhos tecnológicos. (HODSON, 2008) À medida em que surgem as dificuldades, nos projetos de estudantes, o professor pode usar combinações de "modelagem" e "prática guiada", como consta do Apêndice B. Um ponto de partida simples para começar, dependendo das idades dos estudantes, está em vários brinquedos, tais como helicópteros de pape $1^{14}$ - que são feitos de folhas soltas de papel dobrado e cortado para formar um par de "lâminas" e um "rotor" que pode girar no ar, à medida em que são soltos, a partir de diferentes alturas. O professor pode pedir aos estudantes para fazer uma chuva de ideias (brainstorm) sobre os fatores (variáveis) que poderiam influenciar a velocidade de queda dos helicópteros, tais como: massa (com clipes de papel adicionados); comprimento da lâmina; altura; ventos cruzados; espessura do papel; cor das asas etc. Por meio de tentativa e erro, o professor pode debater com os estudantes conceitos mencionados no Apêndice $C$ sobre experimentos, tais como: a duplicação de testes; o controle de variáveis; e a gama de valores relacionados à variável causadora. Dependendo da idade e do estágio dos ASK dos estudantes, e considerando as habilidades e estratégias, como aquelas na Figura 8 e no Apêndice $\mathrm{C}$, os professores podem envolvê-los ainda mais nessas atividades relativamente guiadas, a partir de outras fontes.

14 Ver em: <http://home.frognet.net/ ejcov/helicopter.html>. 
Quadro 1 - Guia de planejamento e avaliação de projetos de RiNA

\begin{tabular}{|c|c|c|c|c|}
\hline $\begin{array}{l}\text { Critérios para pesquisa secundária (1- Emergente; } 2 \text { - Proficiente; } \\
3 \text { - Altamente treinado; } 4 \text { - Exemplar) }\end{array}$ & 1 & 2 & 3 & 4 \\
\hline \multicolumn{5}{|l|}{$\begin{array}{l}\text { A questão CTSA e as possíveis causas da questão estão claramente } \\
\text { descritas em suas próprias palavras }\end{array}$} \\
\hline \multicolumn{5}{|l|}{$\begin{array}{l}\text { Você identificou os atores com poder e suas influências na sua questão } \\
\text { sobre CTSA }\end{array}$} \\
\hline \multicolumn{5}{|l|}{$\begin{array}{l}\text { Você explicou o que você já sabe sobre a questão CTSA na sua } \\
\text { introdução }\end{array}$} \\
\hline \multicolumn{5}{|l|}{$\begin{array}{l}\text { Você abordou algumas (duas ou três) consequências negativas sobre o } \\
\text { bem-estar de indivíduos, sociedades e/ou ambientes }\end{array}$} \\
\hline \multicolumn{5}{|l|}{$\begin{array}{l}\text { A informação que você pesquisou é relevante, detalhada e precisa e } \\
\text { está resumida em aproximadamente } 750 \text { palavras (ou em } 2,5 \text { páginas, } \\
\text { com espaçamento duplo) }\end{array}$} \\
\hline \multicolumn{5}{|l|}{$\begin{array}{l}\text { Você tem ao menos três referências diferentes e usou um formato de } \\
\text { referência apropriado (por exemplo, estilo APA) }\end{array}$} \\
\hline \multicolumn{5}{|l|}{ NÍVEL GERAL DE ALCANCE PARA A PESQUISA SECUNDÁRIA } \\
\hline \multicolumn{5}{|l|}{ Critérios para pesquisa primária } \\
\hline \multicolumn{5}{|l|}{$\begin{array}{l}\text { Sua investigação ajuda a responder uma questão original de causa e } \\
\text { efeito relacionada a sua questão CTSA? (isto é, há correlação entre } \\
\text { gênero [ou idade] e quantidade de comida rápida consumida por } \\
\text { semana?) }\end{array}$} \\
\hline \multicolumn{5}{|l|}{ Sua descrição da sua pesquisa deve ser clara e lógica } \\
\hline \multicolumn{5}{|l|}{$\begin{array}{l}\text { Sua pesquisa é válida e confiável (o tamanho da amostra é grande o } \\
\text { suficiente, ampla variedade de variáveis independentes usadas, na } \\
\text { medida do possível etc.) }\end{array}$} \\
\hline \multicolumn{5}{|l|}{$\begin{array}{l}\text { Seus dados devem ser claramente mostrados em tabelas e gráficos } \\
\text { com as variáveis causa e efeito claramente definidas, junto com as } \\
\text { variáveis controle apropriadas, identificadas abaixo da tabela/gráfico. }\end{array}$} \\
\hline \multicolumn{5}{|l|}{$\begin{array}{l}\text { Seus resultados devem ser interpretados em um texto escrito de } \\
\text { aproximadamente } 300-350 \text { palavras. } \\
\text { - Esboce uma conclusão sobre os possíveis efeitos da variável } \\
\text { causa sobre a variável efeito com uma explicação (sua teoria/ } \\
\text { hipótese) } \\
\text { - Discuta possíveis limitações nos seus resultados ou métodos }\end{array}$} \\
\hline \multicolumn{5}{|l|}{ NÍVEL GERAL DE ALCANCE PARA A PESQUISA PRIMÁRIA } \\
\hline \multicolumn{5}{|l|}{ Critérios para o ativismo sobre CTSA } \\
\hline \multicolumn{5}{|l|}{ Duas ações diferentes são propostas para lidar com a questão CTSA } \\
\hline \multicolumn{5}{|l|}{$\begin{array}{l}\text { As possíveis ações sobre a questão são lógicas (isto é, elas fazem } \\
\text { sentido) }\end{array}$} \\
\hline \multicolumn{5}{|l|}{$\begin{array}{l}\text { Os materiais da ação são prontos para usar, estão facilmente } \\
\text { disponíveis }\end{array}$} \\
\hline \multicolumn{5}{|l|}{ As ações atingem vários grupos, incluindo pessoas no poder } \\
\hline \multicolumn{5}{|l|}{$\begin{array}{l}\text { As ações fazem excelente uso das informações de pesquisas secundária } \\
\text { e primária }\end{array}$} \\
\hline \multicolumn{5}{|l|}{ As ações são bem defendidas na apresentação oral da ação } \\
\hline NÍVEL GERAL DE ALCANCE PARA O PLANO DE AÇÃO & & & & \\
\hline
\end{tabular}

Fonte: elaborado pelos autores. 
Figura 8 - Habilidades e estratégias para a C\&T

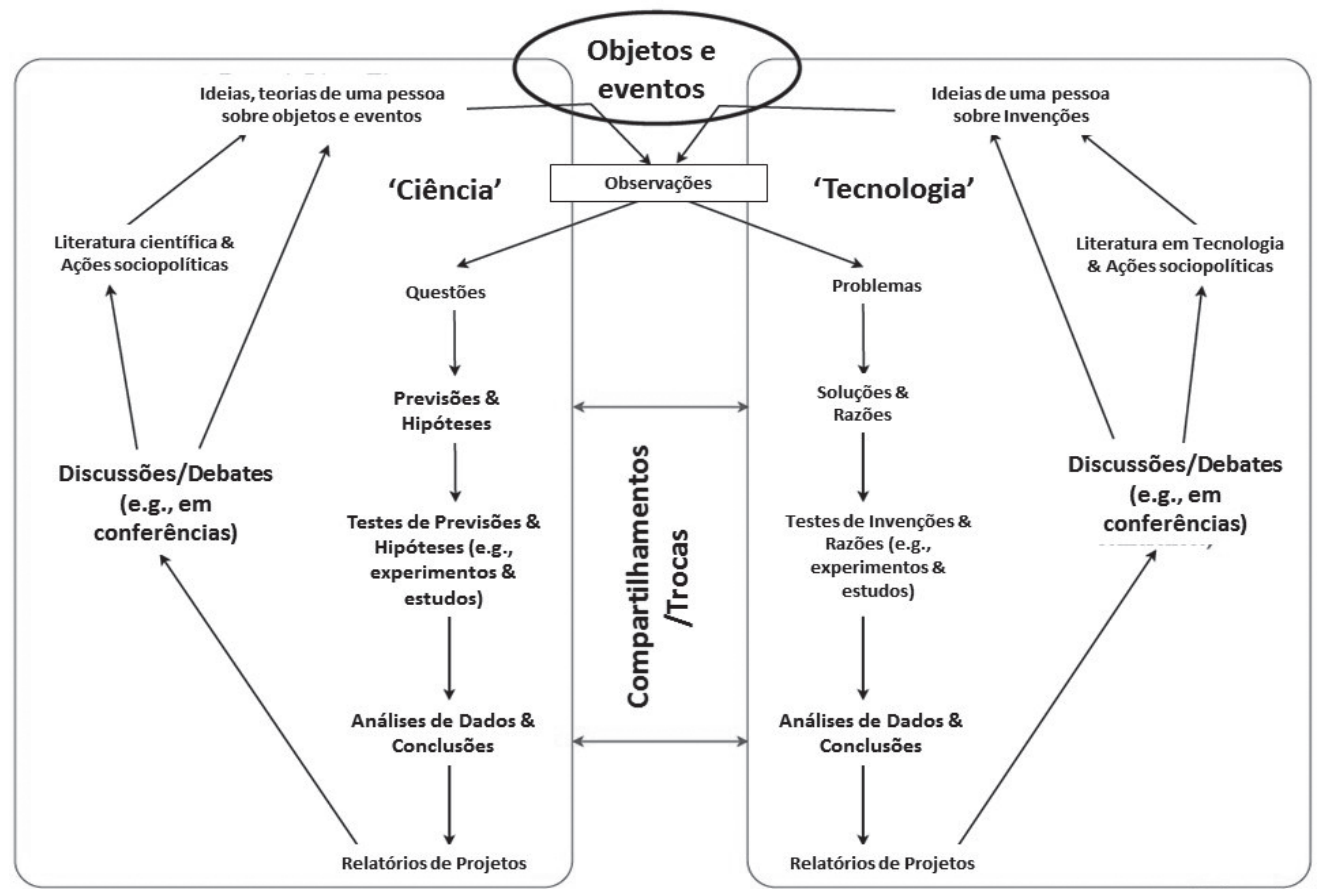

Fonte: elaborada pelos autores.

Ao investigar as relações CTSA, muitas vezes, é particularmente importante a realização de estudos (métodos de pesquisa não experimentais), em vez de experimentos. Devido ao fato de muitas variáveis das relações CTSA serem potencialmente prejudiciais (por exemplo, o desenvolvimento de câncer), é mais ético observar (estudar) mudanças naturais nelas do que forçá-las a ocorrer (como na experimentação). Os estudos podem ser qualitativos e/ou quantitativos. Qualitativamente, é muito comum, por exemplo, entrevistar pessoas (por exemplo, sobre suas opiniões a respeito dos usos de garrafas de água) e/ou para descrever mudanças na natureza (por exemplo, vários processos de envelhecimento em seres vivos). Em termos de análise quantitativa, por sua vez, os investigadores usam frequentemente estudos de correlação; ou seja, investigações empíricas em que os pesquisadores medem variáveis que mudam naturalmente e, em seguida, comparam as alterações entre tais variáveis para determinar a extensão em que as mudanças em uma variável parecem estar influenciando mudanças em outra variável. Tal como acontece com a experimentação, os professores podem usar diferentes abordagens para apresentar aos estudantes estudos de correlação - os quais tendem a não ser enfatizados na educação científica, talvez por causa da relativa facilidade do controle de variáveis em experimentos, quando estes são comparados com estudos não experimentais. (BENCZE, 1996) Uma maneira comum de apresentar estudos, em comparação com experimentos, é perguntar aos estudantes como eles podem determinar as relações en- 
tre as variáveis que envolvem resultados prejudiciais, tais como a forma de descobrir até que ponto os dedos dos fumantes de cigarro se tornam amarelados com o aumento do tabagismo. Alguns estudantes podem rapidamente sugerir que se pergunte às pessoas que já fumam se elas permitem que um investigador meça (por exemplo, com paletas de cores) o amarelecimento dos seus dedos, após o que a pessoa iria ser perguntada quantos cigarros ele/ela fuma, em média, por dia. O professor poderia, então, mostrar aos estudantes exemplos de gráficos de diferentes estudos, tais como: as taxas de câncer vs distância de linhas de energia/eletricidade; taxa de fumo de cigarro vs taxa de câncer; e, número de assentos do automóvel vs pegada de carbono média. Em seguida, os estudantes poderão ser convidados a completar o exercício no Apêndice D - que os provê com alguma prática para o uso de conceitos associados aos estudos de correlação.

Abordagens como aquela acima tiveram um sucesso notável em termos de serem capazes de ter mais controle sobre projetos para RiNA acerca de problemas de CTSA de seu interesse. Um bom exemplo de tal projeto foi realizado por uma estudante do $1^{\circ}$ ano do ensino médio que conduziu uma pesquisa primária e secundária sobre cosméticos e encontrou, por exemplo, vários problemas pessoais, sociais e ambientais associados a esses produtos; e, ainda, que a propaganda foi uma influência esmagadora sobre adolescentes em sua escola, na escolha para utilizá-los. Então, depois de uma análise de rede das relações CTSA sobre cosméticos, ela produziu um vídeo ativista ${ }^{15}$ muito sofisticado e postou no YouTube. Este vídeo ilustra claramente potenciais problemas relacionados com influências de pessoas ou grupos poderosos sobre a C\&T. Apesar de não ter sido evidenciada a pesquisa primária que a estudante, de fato, realizou e descreveu no seu relatório do projeto, o vídeo foi destinado ao público adolescente mais jovem - aqueles que sua pesquisa indicou como mais vulneráveis à publicidade.

\section{Apoiando habilidades para RiNA sobre CTSA: prática reflexiva}

Claramente, nem todos os estudantes são capazes de desenvolver tais vídeos ativistas sofisticados ou outras formas de ação. Tal como acontece com muitas turmas em variados contextos, o alcance dos objetivos está distribuído em uma curva normal (curva de sino) - com alguns poucos projetos "pobres", muitos outros "médios" e alguns trabalhos "excelentes". Quando isso ocorre, os professores podem relutar em pedir a todos os estudantes que autodirijam projetos de RiNA sobre questões CTSA de sua própria escolha (como indicado na Figura 2). Para tornar isso mais viável, no entanto, uma abordagem que parece ter sido bem-sucedida em preparar os estudantes para projetos autodirigidos é pedir a eles que reflitam e compartilhem perspectivas sobre a natureza das relações CTSA e projetos para RiNA. Esta aderência é baseada na metacognição, a ideia de que desenvolver ideias gerais sobre a própria aprendizagem e, em seguida, usá-las (possivelmente revistas pelo pensamento e pela discussão) para guiar a aprendi-

15 Ver em: <https://www.youtube.com/watch?v=WhN6PS1GT9c>. 
zagem futura. (NIEMI, 2002) Por exemplo, em uma aplicação dessa abordagem em sala de aula, após seu segundo conjunto de projetos guiados de mini-RiNA, os estudantes foram convidados a preencher o formulário de avaliação, no Quadro 2, seguindo a ideia do "pense-discuta-compartilhe" (think-pair-share) - com os estudantes, inicialmente completando o formulário de forma individual e, em seguida, compartilhando as suas respostas com os membros do grupo. Isto foi, então, utilizado como base para uma discussão com toda a turma, em que o professor (Krstovic) convidou os estudantes para compartilhar as respostas às suas perguntas e ofereceu algumas ideias novas - como o possível papel das emoções em tais projetos - para consideração do estudante.

Quadro 2 - Formulário para reflexão do estudante sobre projeto de RiNA

\begin{tabular}{|c|}
\hline Reflexão sobre RiNA: para cada questão, indique uma nota e uma breve justificativa \\
\hline Refletindo sobre questões CTSA \\
\hline $\begin{array}{l}\text { Como você se sentiu quando você teve controle sobre que questão CTSA explorar? } \\
\text { [5=muito bem }] \text { o }-1-2-3-4-5\end{array}$ \\
\hline $\begin{array}{l}\text { O quão confiante você está de que você entendeu a controvérsia envolvida na questão que você } \\
\text { estudou? } \\
\text { [5=muito confiante] } 0-1-2-3-4-5\end{array}$ \\
\hline $\begin{array}{l}\text { O quanto as emoções (por exemplo, versus a lógica) influenciaram neste projeto? } \\
{[5=\text { muito }] 0-1-2-3-4-5}\end{array}$ \\
\hline Refletindo sobre a Pesquisa \\
\hline $\begin{array}{l}\text { O quão confiante você está para projetar um estudo válido? } \\
\text { [5=muito confiante] } 0-1-2-3-4-5\end{array}$ \\
\hline $\begin{array}{l}\text { O quão confiante você está nos resultados do seu estudo? } \\
{[5=\text { muito confiante }] 0-1-2-3-4-5}\end{array}$ \\
\hline $\begin{array}{l}\text { O quão confiante você está sobre os achados da sua pesquisa secundária (isto é, pesquisas na internet) } \\
\text { [5=muito confiante] o }-1-2-3-4-5\end{array}$ \\
\hline Refletindo sobre Ações \\
\hline $\begin{array}{l}\text { O quanto sua pesquisa primária e/ou secundária motivou e/ou dirigiu suas ações? } \\
\text { [5=Muito } 0-1-2-3-4-5\end{array}$ \\
\hline $\begin{array}{l}\text { Quanta confiança você tem no que você está recomendando às pessoas (isto é, suas recomendações } \\
\text { de ação)? [5=Muita] o - 1-2-3-4-5 }\end{array}$ \\
\hline $\begin{array}{l}\text { O quanto você sentiu que o modo que você apresentou sua informação teve um efeito (positivo ou } \\
\text { negativo) na sua audiência? } \\
\text { [5=Teve um grande efeito] } 0-1-2-3-4-5\end{array}$ \\
\hline $\begin{array}{l}\text { Em que medida você sente que suas ações alcançaram pessoas com poder? } \\
\text { [5=Muito] } 0-1-2-3-4-5\end{array}$ \\
\hline $\begin{array}{l}\text { O quanto você sente que suas ações (por exemplo, seus pôsteres, vídeos, folhetos, panfletos etc.) se } \\
\text { tornaram parte de uma rede que modifica as mensagens dominantes (por exemplo, apesar de comida } \\
\text { rápida ser saboroso, seus pôsteres/folhetos/panfletos/vídeos etc., se tornaram representações que } \\
\text { desafiam a mensagem dominante, propagada pelas companhias de comida rápida)? } \\
\text { [5=Muito] } 0-1-2-3-4-5\end{array}$ \\
\hline Refletindo sobre Colaboração \\
\hline $\begin{array}{l}\text { O quanto a colaboração de pares (isto é, trabalho em grupo) funciona bem para este tipo de projeto? } \\
{[5=\text { Muito Bem }] \circ-1-2-3-4-5}\end{array}$ \\
\hline $\begin{array}{l}\text { Em que medida o compartilhamento/colaboração com outros grupos ativistas afeta este trabalho? Se } \\
\text { sim, apresente exemplos. [5=Muito] } 0-1-2-3-4-5\end{array}$ \\
\hline O que todos estes projetos de RiNA tem em comum em termos de questões, pesquisa e ações? \\
\hline
\end{tabular}

Fonte: elaborado pelos autores. 


\section{Projetos de RiNA liderados por estudantes: desafios e oportunidades}

Uma vez que o professor tenha decidido que os estudantes estão prontos para essa nova etapa, ele deve apresentar a eles um projeto de RiNA liderado por estudantes para resolver um problema CTSA de interesse deles. No contexto da sala da aula, no entanto, é muito difícil para os professores, inseridos nos sistemas educativos formais, separarem-se totalmente dos projetos dos estudantes. Um dos maiores desafios é encorajar a tomada de decisão dos estudantes, ao mesmo tempo em que se proporciona a eles um esquema que será utilizado para avaliar cada etapa do projeto e, abertamente, para motivá-los para concluí-las. O projeto de RiNA, fornecido no Apêndice E, representa uma tentativa de equilibrar a tomada de decisão do estudante e as intenções das escolas para avaliar e registrar o desempenho destes. Devido à necessidade de avaliar e registrar o progresso do estudante, em grande medida, a independência proporcionada por esses projetos dependerá da flexibilidade do professor em aceitar uma variedade de níveis de desempenho como "satisfatórios". Tais julgamentos são, sem dúvida, complexos - feitos com base em vários fatores, tais como julgamentos dos professores sobre as capacidades dos estudantes, em termos de suas idades, estágios de aprendizagem etc. e, como já referido acima, também dependem das crenças do professor sobre a Natureza da Ciência. Os professores com posições mais naturalistas-antirrealistas sobre a ciência são, sem dúvida, mais propensos a aceitar uma maior variedade de desempenhos dos estudantes do que professores que aderem aos pontos de vista mais racionalistas-antirrealistas.

A partir das nossas experiências, se existe o alinhamento de uma gama de condições, incluindo ter um professor comprometido com uma educação CTSA crítica e projetos de RiNA autodirigidos, o pessoal de suporte da escola (por exemplo, administradores e colegas professores) e encargos curriculares para a educação CTSA e para a pesquisa liderada por estudantes, é muito provável que os estudantes sejam capazes de realizar projetos de RiNA autodirigidos, de alto nível, sobre questões CTSA de sua própria escolha, depois de apenas uma ou duas séries de aulas e atividades de aprendizagem mediada (estudantes mais velhos parecem precisar de apenas uma série de aprendizagem mediada). Evidências de tais alcances podem ser encontradas em uma edição especial do periódico Journal for Activist Science and Technology Education (JASTE), ${ }^{16}$ uma revista de código-fonte aberto, não arbitrada, com artigos escritos por estudantes do ensino médio sobre os seus projetos de RiNA. Esta edição especial, editada por Mirjan Krstovic, tem atraído consideráveis elogios de várias fontes, incluindo os colegas de ensino e de administração de Mirjan, assim como os colegas de Larry, local e internacionalmente. A um nível mais local, enquanto isso, Mirjan e seus estudantes receberam considerável apreciação dos projetos apresentados na biblioteca da escola em uma feira sobre RiNA e CTSA (algo como uma feira de ciências). Os professores, que excursionaram os projetos em exposição - incluindo o ilustrado na Figura 9 -, fomentaram o engajamento dos

16 Ver em: <http://jps.library.utoronto.ca/index.php/jaste/issue/view/1560>. 
estudantes em discussões sobre os seus projetos e ficaram muito impressionados com a criatividade, a experiência e o compromisso dos estudantes para lidar com controvérsias sobre CTSA complexas e importantes.

Figura 9 - Feira sobre RiNA e CTSA: consumo de cigarros

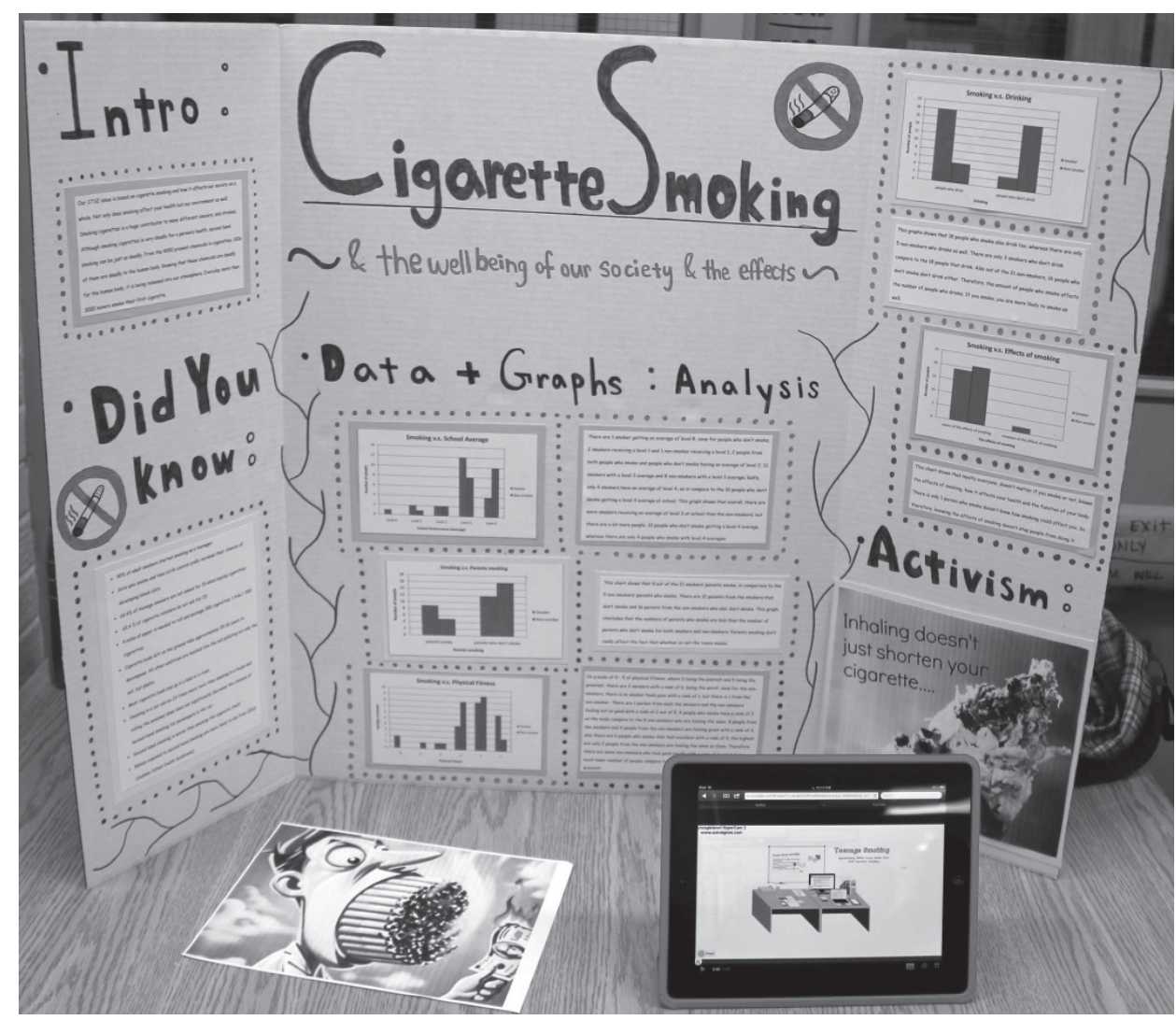

Fonte: elaborada pelos autores.

\section{Síntese e conclusões}

O framework STEPWISE tem permitido aos estudantes desenvolver e implementar planos de ação que "consomem" ao menos uma parte do letramento deles na tentativa de abordar problemas que eles identificam nas relações entre os campos CTSA. Em muitos casos, os estudantes parecem desenvolver uma preocupação genuína pelo bem-estar do outro; por exemplo, outras pessoas e outros seres vivos e não vivos que parecem estar em risco nas relações CTSA. Talvez relacionada a tal empatia, os estudantes pareçam desenvolver entusiasticamente a própria perícia de que eles precisam para aprender mais sobre tais riscos e, com base nos conhecimentos e atitudes disponíveis, podem realizar ações para abordar os problemas identificados. 
Em outras palavras, sementes são plantadas nas mentes de muitos estudantes prontos para desenvolver e nutrir a si mesmos e a outros em vários contextos importantes. Nós temos visto, além disso, algumas situações melhorarem - tais como autoridades escolares aperfeiçoando seus programas de reciclagem de lixo - em virtude de ações dos estudantes.

Embora seja difícil medir, é evidente que as ações dos estudantes, ao mesmo tempo em que entusiasmadas, muitas vezes possuem efeitos relativamente pequenos, além de seus ambientes mais imediatos da casa, da escola e das comunidades locais. Por exemplo, não que esta seja a melhor ação de um estudante de nossa pesquisa, mas muitos acadêmicos, professores e outros a quem temos mostrado o vídeo ativista sobre cosméticos (ver acima) têm elogiado esta ação; mas, ainda assim, ele foi visto por apenas pouco mais de 500 vezes (até 17 de setembro de 2017). Ele não se tornou viral. Estamos interessados, portanto, em novas abordagens, que possam gerar benefícios mais generalizados a partir das ações dos estudantes. Em um recente estudo em curso de ações baseadas em pesquisa por cidadãos, para buscar resolver um caso de contaminação ambiental em sua comunidade local, no entanto, tornou-se evidente que grande parte dos sucessos dos cidadãos parecia se relacionar com a criação de redes de suas ações. (BENCZE; POULIOT, 2017) Ou seja, depois de um ato inicial de pagar um laboratório local para testar a poeira que estava se acumulando em seu ambiente, uma rede complexa de actantes vivos (por exemplo, cidadãos e grupos de colegas), não-vivos (por exemplo, um site ativista) e simbólicos (por exemplo, um sentimento de indignação) se alinharam em apoio a uma causa relacionada (por exemplo, ações de mitigação cívicas e corporativas). Esta rede de ação (action-network) pareceu resultar em algumas respostas positivas, incluindo mudanças no monitoramento da qualidade do ar e redução do nível mínimo permitido de poluentes. (POULIOT, 2015) Assim, parece claro que os educadores podem querer incentivar os estudantes a trabalhar em rede tanto nas suas pesquisas sobre as relações CTSA (PIERCE, 2013) quanto sobre suas ações. (BENCZE; POULIOT, 2017)

Encorajar e permitir ações negociadas e informadas por pesquisa, autodirigidas e em rede, pelos próprios estudantes, para abordar os problemas CTSA, embora aparentemente possível em alguns contextos, parece ser uma tarefa assustadora. Como mencionado acima, tem sido a nossa experiência que a realização de tais projetos críticos e altruístas é algo raro - exigindo o alinhamento de uma grande variedade de actantes, incluindo um professor com experiência, confiança e motivação correspondentes, colegas e pessoal administrativo, além de encargos curriculares, que oferecem suporte. Além disso, as perspectivas para as suas formações parecem particularmente ameaçadas nos últimos anos - talvez simbolizada melhor pela rápida emergência e pelas influências generalizadas da educação para Ciência, Tecnologia, Engenharia e Matemática (STEM). Embora pareça haver justificativa significativa para a integração e/ou inter-relações entre os quatro campos STEM na educação, incluindo em termos de relações profissionais (RENNIE; VENVILLE; WALLACE, 2012), estudos de documentos e políticas curricula- 
res em apoio a este tipo de educação, muitas vezes, parecem indicar que eles priorizam o ensino e a aprendizagem das habilidades e dos conhecimentos amplamente aceitos e competências dos campos da educação STEM, enquanto, aparentemente, com uma atenção zelosamente omitida sobre os problemas associados às relações entre CTSA e ações para resolvê-los. (GOUGH, 2015; ZEIDLER, 2016) Aparentemente, uma chave para o que pode estar conduzindo a educação STEM não reside tanto nos campos incluídos; mas, sim, naqueles que são excluídos. Particularmente ausente nesta combinação, estão os campos das ciências humanas e sociais. Os discursos em políticas educacionais e em documentos de currículos parecem suportar esta conclusão e, além disso, apontam orientadores socioeconômicos da educação STEM. O Conselho Nacional de Pesquisa dos EUA (NRC, 2011), por exemplo, que ajudou a facilitar o desenvolvimento dos padrões curriculares Next Generation Science Standards (Achieve, uma empresa privada), no seu documento, denominado educação STEM bem-sucedida, declara que:

[O] principal motor da economia do futuro e concomitante criador de postos de trabalho será a inovação, em grande parte derivada de avanços em ciência e engenharia... 4 por cento da força de trabalho do país é composta de cientistas e engenheiros; este grupo cria desproporcionalmente postos de trabalho para os outros 96 por cento. (NATIONAL RESEARCH COUNCIL, 2011, p. 2)

Tal discurso parece sugerir que a educação STEM está principalmente preocupada em identificar e educar relativamente poucos profissionais da educação STEM que podem desenvolver e gerir mecanismos e pessoal para a produção e o consumo de bens e serviços que possam enriquecer financistas e empresas que financiam em grande parte o trabalho daqueles. (MEANS, 2013; PIERCE, 2013) De forma mais ampla, como McLaren (2000, p. 196) afirmou, parece que "[...] o principal propósito da educação é tornar o mundo seguro para o capitalismo global”.

Os educadores, implementando programas críticos e altruístas, como o STEPWISE, podem ter que enfrentar um "Borg"17 virtual; ou seja, um "complexo homem-tecnologia" agindo como um único ser que ameaça assimilar tudo em seu caminho para a sua rede. Em um estudo de instituições educacionais em relações as entidades do setor privado, por exemplo, Ball (2012) concluiu que os membros deste setor mantêm seu poder e influência sobre as sociedades em grande parte através de uma vasta e crescente rede interconectada de actantes alinhados para apoio ao lucro privado. No estudo mencionado acima, das ações dos cidadãos para eliminar o que eles concluem ser poeira tóxica que está sendo espalhada em toda a sua comunidade, estes cidadãos têm expressado preocupação de que as ações para eliminar a poeira são mínimas - em grande parte devido ao poder de uma rede pró-capitalista de actantes, como o governo local, prio-

17 Ver em: <https://en.wikipedia.org/wiki/Borg_(Star_Trek)>. 
rizando empregos e receitas fiscais e as empresas associadas mais estreitamente com a dispersão de poeira tóxica que estão priorizando a expansão de seus lucros e operações. (BENCZE; POULIOT, 2017) Sob esta perspectiva, parece que, talvez, a única saída, para aqueles que apoiam programas educacionais críticos e altruístas, como os baseados no STEPWISE, seja, talvez ironicamente, imitar o setor privado - no sentido de reunir muitos actantes para suas causas. Tal projeto não seria como uma batalha de "David contra Golias"; mas, ao contrário, pode ser visto mais como um movimento de massa - com perspectivas e práticas "de ir se tornando viral", ao engajar uma grande variedade de adeptos.

\section{Referências}

ANGELL, M. The truth about the drug companies: how they deceive us and what to do about it. New York: Random House, 2004.

BALL, S. J. Global education Inc.: new policy networks and the neo-liberal imaginary. Abingdon: Routledge, 2012.

BARNES, R. L.; HAMMOND, S. K.; GLANTZ, S. A. The tobacco industry's role in the 16 Cities Study of Secondhand Tobacco Smoke: Do the data support the stated conclusions? Environmental Health Perspectives, Research Triangle Park, n. 114, v. 12, p. 1890-1897, 2006.

BAUDRILLARD, J. The consumer society. London: Sage, 1998.

BENCZE, L. Student-led learning for 'altruistic' socio-political actions. In: SHAPIRO, B. (Ed.). Actions of their own to learn. Rotterdam: Sense, 2018. p. 177-198.

BENCZE, L. Correlational studies in school science: Breaking the science-experimentcertainty connection. School Science Review, London, v. 78, n. 282, p. 95-101, 1996.

BENCZE, L. STEPWISE: A framework prioritizing altruistic actions to address socioscientific issues. In: BENCZE, J. L. (Ed.). Science \& technology education promoting wellbeing for individuals, societies \& environments. Dordrecht: Springer, 2017. p. 19-45.

BENCZE, L.; ALSOP, S. (Ed.). Activist science \& technology education. Dordrecht: Springer, 2014.

BENCZE, L.; BOWEN, M.; ALSOP, S. Teachers' tendencies to promote student-led science projects: Associations with their views about science. Science Education, Leeds, v. 90, n. 3, p. 400-419, 2006.

BENCZE, L.; CARTER, L. Globalizing students acting for the common good. Journal of Research in Science Teaching, New York, v. 48, n. 6, p. 648-669, 2011.

BENCZE, L.; ELSHOF, L. Science teachers as metascientists: An inductive-deductive dialectic immersion in northern alpine field ecology. International Journal of Science Education, London, v. 26, n. 12, p. 1507-1526, 2004. 
BENCZE, L.; KRSTOVIC, M. Resisting the Borg: Science teaching for common wellbeing. In: BENCZE, J. L. (Ed.). Science \& technology education promoting wellbeing for individuals, societies \& environments. Dordrecht: Springer, 2017. p. 227-276.

BENCZE, L.; POULIOT, C. Science \& technology promoting wellbeing for individuals, societies \& environments. In: BENCZE, J. L. (Ed.). Science \& technology promoting wellbeing for individuals, societies \& environments. Dordrecht: Springer, 2017. p. 381404.

BOURDIEU, P. The forms of capital. In: RICHARDSON, J. G. (Ed.). The handbook of theory: Research for the sociology of education. New York: Greenwood Press, 1986. p. 241-258.

COBERN, W. W.; LOVING, C. C. The card exchange: Introducing the philosophy of science. In: MCCOMAS, W. F. (Ed.). The nature of science in science education. Dordrecht: Kluwer, 1998, p. 73-82.

GOTT, R.; DUGGAN, S. Understanding and using scientific evidence: how to critically evaluate data. London: Sage, 2003.

GOUGH, A. STEM policy and science education: Scientistic curriculum and sociopolitical silences. Cultural Studies of Science Education, Dordrecht, v. 10, n. 2, p. 445-458, 2015.

HILEMAN, B. Industry's privacy rights: Is science short changed? Chemical \& Engineering News, Washington, p. 36, v. 76, n. 36, 1998.

HODSON, D. Looking to the future: building a curriculum for social activism. Rotterdam: Sense, 2011.

HODSON, D. Towards scientific literacy: a teachers' guide to the history, philosophy and sociology of science. Rotterdam: Sense, 2008.

KHISHFE, R.; LEDERMAN, N. G. Teaching nature of science within a controversial topic: integrated versus nonintegrated. Journal of Research in Science Teaching, New York, v. 43, n. 4, p. 395-418, 2006.

KLEIN, N. This changes everything: capitalism and the climate. Toronto: Simon \& Schuster, 2014.

KLEINMAN, D. L. Impure cultures: University biology and the world of commerce. Madison, WI: University of Wisconsin Press, 2003.

KRIMSKY, S. Science in the private interest: has the lure of profits corrupted biomedical research? Lanham, MD: Rowman \& Littlefield, 2003.

LATOUR, B. Reassembling the social: an introduction to actor-network-theory. Oxford: Oxford University Press, 2005.

LEONARD, A. The story of stuff: how our obsession with stuff is trashing the planet, our communities, and our health - and a vision for change. New York: Free Press, 2010 . 
LEVINSON, R. Science education and democratic participation: An uneasy congruence? Studies in Science Education, Leeds, v. 46, n. 1, p. 69-119, 2010.

LEVINSON, R. Practice and theory of socio-scientific issues: An authentic model? Studies in Science Education, Leeds, v. 49, n. 10, p. 99-116, 2013.

LOCK, R. Open-ended, problem-solving investigations: What do we mean and how can we use them? School Science Review, London, v. 71, n. 256, p. 63-72, 1990.

LOVING, C. C. The scientific theory profile: A philosophy of science model for science teachers. Journal of Research in Science Teaching, New York, v. 28, n. 9, p. 823-838, 1991.

MCLAREN, P. Che Guevara, Paulo Freire, and the pedagogy of the revolution. Lanham, MD: Rowman \& Littlefield, 2000.

MCMURTRY, J. The cancer stage of capitalism: from crisis to cure. London: Pluto, 2013.

MEANS, A. Creativity and the biopolitical commons in secondary and higher education. Policy Futures in Education, Oxford, v. 11, n. 1, p. 47-58, 2013.

MIROWSKI, P. Science-mart: Privatizing American science. Cambridge: Harvard University Press, 2011.

NATIONAL RESEARCH COUNCIL - NRC. Successful K12 STEM education: Identifying effective approaches in science, technology, engineering, and mathematics. Washington: National Academies Press, 2011.

NIEMI, H. Active learning-a cultural change needed in teacher education and schools. Teaching and Teacher Education, New York, v. 18, n. 7, p. 763-780, 2002.

OSBORNE, R.; WITTROCK, M. The Generative Learning Model and its implications for science education. Studies in Science Education, Leeds, v. 12, p. 59-87, 1985.

PEDRETTI, E.; NAZIR, J. Currents in STSE education: mapping a complex field, 40 years on. Science Education, Salem, v. 95, n. 4, p. 601-626, 2011.

PIERCE, C. Education in the age of biocapitalism: optimizing educational life for a flat world. New York: Palgrave Macmillan, 2013.

POULIOT, C. Quand les citoyen.ne.s soulèvent la poussière: la Controverse Autour de la Poussière Métallique à Limoilou Montréal: Carte blanche, 2015.

RENNIE, L.; VENVILLE, G.; WALLACE, J. (Ed.). Integrating science, technology, engineering and mathematics: issues, reflections and ways forward. New York: Routledge, 2012.

SADLER, T. D.; BARAB, S. A.; SCOTT, B. What do students gain by engaging in socioscientific inquiry? Research in Science Education, Amsterdam, v. 37, n. 4, p. 371391, 2007.

VASIL, A. Ecoholic: Your guide to the most environmentally friendly information, products and services in Canada. Toronto: Vintage, 2007. 
WEBER, K. (Ed.). Food inc.: how industrial food is making us sicker, fatter, and poorer - and what you can do about it, a participant media guide. New York: Public Affairs, 2009.

WENGER, E. Communities of practice. Cambridge: Cambridge University Press, 1998.

WOOD, G. H. Democracy and the curriculum. In: BEYER, L. E.; APPLE, M. W. (Ed.). The curriculum: problems, politics and possibilities. Albany: SUNY Press, 1998. p. $177-$ 198.

ZEIDLER, D. L. STEM education: A deficit framework for the twenty first century? A sociocultural socioscientific response. Cultural Studies of Science Education, Dordrecht, v. 11, n. 1, p. 11-26, 2016. 


\section{Apêndice A - Estudo de caso da QSC}

\section{DIAMANTES DE SANGUE}

\section{Introdução}

Os diamantes são, essencialmente, formas comprimidas de carbono - formados naturalmente como estruturas cristalinas cúbicas em grandes profundidades no manto da Terra ao longo de pelo menos um bilhão de anos, em condições de alta pressão e temperatura. Eles podem aparecer perto da superfície da Terra por meio de erupções vulcânicas. Então eles podem ser extraídos. Engenheiros também podem produzir diamantes e substâncias similares através de diferentes técnicas.

Os diamantes têm sido valorizados pelas pessoas durante séculos, por causa, por exemplo, de suas propriedades reflexivas e dispersivas (por exemplo, brilho e espectros de cor em gemas), condutividade eléctrica (por exemplo, em semicondutores) e dureza (por exemplo, para uso em brocas). Por causa do valor atribuído a eles, as pessoas, as organizações e os países associados a eles têm aumentado a sua riqueza e prosperidade. As pessoas têm, assim, apreciado diamantes para seu uso em vários ornamentos, inclusive na forma de anéis de casamento e decoração em relógios de pulso.

Apesar dos valores associados aos diamantes, sua extração, sua distribuição, seu processamento e sua venda não ocorrem sem controvérsia. Ironicamente, enquanto eles podem trazer grande felicidade para algumas pessoas (por exemplo, noivas em casamento), eles podem causar grande dor para aqueles envolvidos na sua extração. Consequentemente, há muitas questões complexas para várias partes interessadas - incluindo mineradores, empresas de mineração, governos, varejistas e agências de publicidade. Como os campos da ciência e da tecnologia estão envolvidos de vários modos, e porque há diferenças de opinião sobre o mérito das decisões que as pessoas podem tomar com relação a diamantes, este tema é um excelente exemplo de uma questão sociocientífica.

\section{Problemas dos Diamantes}

Há vários problemas ou potenciais problemas que estão associados com a mineração, a distribuição, o refinamento, o marketing e as vendas de diamantes etc. Alguns deles são brevemente apontados a seguir:

\section{A fixação dos preços}

Os diamantes são, geralmente, muito caros - alegadamente porque eles são relativamente raros e caros para minerar e processar. Contudo, em 2004, De Beers, uma empresa gigante de diamantes, confessou culpa por fixação de preço - por meio, por exemplo, de retenção dos diamantes para criar a ilusão de escassez. Quando a oferta de uma mercadoria é alta, pode fazer parte dos interesses de uma empresa com fins lucrativos criar uma ilusão de escassez para justificar aumento de preços.

Em grande medida, para aumentar artificialmente os preços e, por conseguinte, aumentar os lucros, muitos tipos de empresas contratam empresas de marketing ou empregam técnicas de marketing para criar a ilusão de necessidade; por exemplo, os desejos nos consumidores. (BARBER, 2007) Esta parece ser uma importante estratégia das empresas de diamantes - a tentativa de convencer os parceiros de casamento, por exemplo, de que é natural que anéis de diamantes sejam trocados por votos de casamento. ${ }^{2}$ No entanto, há a sugestão de que, uma vez comprado e adquirido de uma loja de jóias, o valor dos diamantes deprecia.3 Sob esta ótica, os diamantes podem não "ser para sempre", como os comerciantes afirmam frequentemente. Finalmente, parece existir uma canalização do preço do diamante, à medida em que os benefícios financeiros crescentes advêm das pessoas envolvidas diretamente na dura produção de diamantes para as vendas e os ganhos financeiros dos acionistas. Este parece ser um arranjo estrutural típico do capitalismo; aqueles que possuem e fornecem os meios de produção colhem o máximo de benefícios às custas dos verdadeiros trabalhadores.

\section{Ética da externalização}

Uma estratégia importante das empresas e dos financiadores para maximizar o lucro é evitar proativamente vários tipos de custos sociais e ambientais, agindo para garantir que outros assumam a responsabilidade por eles. Bakan (2004, p. 20), em A Corporação (The Corporation), por exemplo, provocativamente sugere que "a corporação ... é uma máquina de externalização, da mesma maneira que um tubarão é uma máquina de matar" e que isso a torna "potencialmente muito, muito prejudicial para a sociedade". A ética subjacente parece ser que efeitos colaterais negativos, pelos quais outros seriam os responsáveis, é uma parte natural de se fazer negócios - para garantir que acionistas obtenham os retornos máximos em seus investimentos. 
A mineração de diamantes apresenta muitos riscos significativos para ambientes locais. Os problemas potenciais do Projeto Victor Mine no Nordeste de Ontário 4 apresentam um exemplo relevante, levando potencialmente a uma série de problemas ambientais, incluindo: i) adição de sal a rios locais, ii) redução da vazão de rios locais, iii) remoção de vegetação natural, iv) interrupção dos movimentos de aves migratórias. Apesar dos riscos potenciais, é evidente que De Beers vai colher os seus lucros durante a vida prevista de 15 anos da mina e, em seguida, deixará as pessoas locais e o governo de Ontário para que lidem com quaisquer efeitos colaterais negativos. No entanto, o governo de Ontário tem, aparentemente, geralmente ignorado as avaliações ambientais e permitido que a operação da mina continue. ${ }^{5}$

A localização de depósitos de diamantes, muitas vezes cria situações em que as pessoas, incluindo os povos indígenas, são deslocados de suas terras. Muitas famílias indígenas, por exemplo, foram deslocadas de suas terras no Zimbabwe ${ }^{6}$ por causa das operações de mineração. Por outro lado, estes povos ${ }^{7}$ recentemente ganharam acesso aos lucros das empresas de diamantes - embora isso possa ser um pequeno consolo para os custos ambientais e sociais já existentes ou ainda por vir.

Talvez o aspecto mais preocupante do negócio de diamantes esteja nas atrocidades frequentemente sofridas pelas pessoas mais pobres. Entre 1971 e 2001, por exemplo, a guerra civil assolou Angola ${ }^{8}$ enquanto governos e as forças antigovernamentais (rebeldes) disputaram o controle das operações de mineração de diamantes. Da mesma forma, a guerra no Congo levou a milhões de mortes. ${ }^{9}$ Uma prática ultrajante dos rebeldes era mutilar milhões de cidadãos, cortando suas mãos, ${ }^{10}$ de modo que não poderiam trabalhar nas operações de mineração patrocinadas pelo governo.

O público em geral tem se tornado consciente da natureza terrível do conflito sobre os lucros dos diamantes, em particular através de filmes como Diamante de Sangue (Blood Diamond) ${ }^{11}$ e organizações como a Global Witness. ${ }^{12}$ Como consequência, um esquema de certificação governamental internacional, conhecido como o Processo Kimberley' ${ }^{13}$ foi lançado, em 2003, para garantir que "diamantes de conflito" não cheguem ao mercado para as vendas. No entanto, já que seu foco está nos diamantes brutos (uma vez que grande parte da regulação não é obrigatória e também porque nem todos os países aceitam o esquema de certificação), os diamantes de conflito parecem continuar a chegar aos mercados. ${ }^{14}$ Ao mesmo tempo, é também evidente que as práticas nas minas de diamantes, como em muitas outras indústrias, muitas vezes empregam crianças ${ }^{15}$ que oferecem um custo baixo por sua mão de obra, para maximizar o lucro.

Por causa dos muitos problemas potenciais associados com diamantes, muitos grupos e indivíduos, como um blogueiro, ${ }^{16}$ estão convocando boicotes à indústria do diamante, se as regulações não aumentarem.

\section{Referências}

BAKAN, J. The corporation: the pathological pursuit of profit and power. Toronto: Viking, 2004.

BARBER, B. R. Consumed: how markets corrupt children, infantilize adults, and swallow citizens whole. New York: Norton, 2007.

\section{Notas:}

$1 \quad$ http://www.corpwatch.org/article.php?id=11431

2 http://science.howstuffworks.com/environmental/earth/geology/diamond5.htm

3 http://www.theatlantic.com/magazine/archive/1982/02/have-you-ever-tried-to-sell-a-diamond/4575/

4 http://www.wildlandsleague.org/display.aspx?pid=231\&cid=233

5 http://www.miningwatch.ca/en/home/country/canada/ontario/victor-project

6 http://www.dailynews.co.zw/opinion/218-displaced-communities-need-protection.html

7 http://www.galdu.org/web/index.php?odas=5116\&giellal=eng

8 http://wwwl.american.edu/ted/ice/angola.htm

9 http://www.msnbc.msn.com/id/15842522/ns/world_news/t/diamonds-journey-beginning/

10 http://www.un.org/peace/africa/Diamond.html

11 http://en.wikipedia.org/wiki/Blood_Diamond_(film)

12 http://www.globalwitness.org/campaigns/conflict/conflict-diamonds

13 http://www.globalwitness.org/campaigns/conflict/conflict-diamonds/kimberley-process

14 http://www.hrw.org/en/news/2009/11/06/kimberley-process-zimbabwe-action-mars-credibility

15 http://en.wikipedia.org/wiki/Child_labour_in_the_diamond_industry

16 http://feministilicious.tumblr.com/post/6356286137/10-reasons-why-you-should-never-buy-diamonds 


\section{Apêndice B - Aprendizagem mediada para habilidades de investigação, projetos, comunicação \& ações}

Para ajudar os estudantes a desenvolver Atitudes, Habilidades e Conhecimentos (ASK) que, ao final, serão relevantes para que eles autodirijam pesquisas científicas a fim de aprender mais sobre os fenômenos, comunicar seus resultados a outros e, quando eles detectam problemas, desenvolver ações pessoais e sociais (incluindo petições, cartazes \& invenções novas/melhoradas), os professores podem conduzir aulas pertinentes de aprendizagem mediada, com atividades dos estudantes. Estes devem começar por perguntar aos estudantes sobre suas ASK pré-instrucionais relacionando-as à investigação, ao projeto e às ações. Mas, então, para ajudar a melhorar os seus ASK, os professores devem "modelar" (ou demonstrar) diferentes ASK e, em seguida, dar aos estudantes a oportunidade de praticá-los em situações significativas, com a orientação que for necessária.

\begin{tabular}{|c|c|c|}
\hline $\begin{array}{l}\text { Habilidades de } \\
\text { Investigação, Projeto, } \\
\text { Comunicação \& } \\
\text { Ações }\end{array}$ & $\begin{array}{c}\text { MODELAGEM } \\
\text { (Demonstrações interativas do professor) }\end{array}$ & $\begin{array}{c}\text { PRÁTICA GUIADA } \\
\text { (Prática do estudante, com assistência } \\
\text { do professor) }\end{array}$ \\
\hline $\begin{array}{l}\text { Observações } \\
\text { qualitativas vs } \\
\text { quantitativas }\end{array}$ & $\begin{array}{l}\text { - Defina o conceito de "variável" e fale aos } \\
\text { estudantes sobre os dois tipos de observações, com } \\
\text { exemplos; em seguida, leve-os a contribuir, cada um } \\
\text { com suas observações baseadas na unidade. } \\
\text { - Demonstre várias habilidades de medição } \\
\text { e descrição; por exemplo, o uso de cilindros } \\
\text { graduados; os usos dos cinco sentidos para } \\
\text { observações qualitativas. }\end{array}$ & $\begin{array}{l}\text { - Peça aos estudantes para brincar } \\
\text { com fenômenos simples - como } \\
\text { balões - e listar cerca de cinco tipos } \\
\text { de observação. } \\
\text { - Peça aos estudantes para medir } \\
\text { quantidades específicas com } \\
\text { aparelhos; por exemplo, a medição do } \\
\text { diâmetro com um micrômetro. }\end{array}$ \\
\hline $\begin{array}{l}\text { Questionamentos, } \\
\text { predições e } \\
\text { levantamento de } \\
\text { hipóteses }\end{array}$ & $\begin{array}{l}\text { - Apresente e discuta as relações entre } \\
\text { variável causa (independente) e variável efeito } \\
\text { (dependente), usando fenômenos comuns, de } \\
\text { rápida visualização, como fenômenos visuais; } \\
\text { por exemplo, mergulhador Cartesiano ou ludião, } \\
\text { balões etc.; } \\
\text { - Mostre-lhes, com exemplos, listas de possíveis } \\
\text { variáveis de causa e variáveis de efeito que } \\
\text { podem ser combinadas para desenvolver } \\
\text { questões e previsões. }\end{array}$ & $\begin{array}{l}\text { - Coloque os estudantes para } \\
\text { desenvolver questões sobre relações } \\
\text { causa-efeito, previsões e hipóteses } \\
\text { com fenômenos comuns; } \\
\text { - Peça aos estudantes para completar } \\
\text { declarações sobre relações de } \\
\text { causa-efeito; por exemplo, quanto } \\
\text { maior _-_________, mais dura será a } \\
\text { gelatina. }\end{array}$ \\
\hline $\begin{array}{c}\text { Projetar e conduzir } \\
\text { experimentos; isto é, } \\
\text { testes empíricos dos } \\
\text { efeitos de mudanças } \\
\text { intencionais em uma } \\
\text { possível variável causa } \\
\text { sobre mudanças em } \\
\text { uma possível variável } \\
\text { efeito. }\end{array}$ & $\begin{array}{l}\text { - Conduza demonstrações interativas (por } \\
\text { exemplo, bolas quicando em superfícies diferentes) } \\
\text { que ilustram e justificam vários fatores a levar em } \\
\text { conta em projetos de estudos e experimentos; } \\
\text { incluindo: i) utilizar um amplo intervalo de } \\
\text { valores (quantidades) da possível variável causa; } \\
\text { ii) duplicar o teste de cada quantidade/valor; iii) } \\
\text { medir e descrever variáveis, onde for apropriado; } \\
\text { iv) checar duplamente cada medição e/ou } \\
\text { descrição (confiabilidade); v) controlar os efeitos } \\
\text { de variáveis intervenientes; vi) comparar variáveis } \\
\text { de resultados para verificar a validade. }\end{array}$ & $\begin{array}{l}\text { - Forneça aos estudantes materiais } \\
\text { e descrições de experimentos para } \\
\text { eles projetarem e realizarem os seus } \\
\text { próprios; por exemplo, efeitos de } \\
\text { diferentes variáveis; por ex.: i) massa } \\
\text { do helicóptero de papel vs taxa } \\
\text { de descida; ii) espessura de faixas } \\
\text { elásticas vs distância percorrida } \\
\text { quando esticado e liberado; iii) dureza } \\
\text { da superfície (por exemplo, tapete vs } \\
\text { madeira) vs altura de pulo da bolinha } \\
\text { etc. }\end{array}$ \\
\hline $\begin{array}{l}\text { Projetar e conduzir } \\
\text { estudos de correlação; } \\
\text { isto é, testes empíricos } \\
\text { dos efeitos de } \\
\text { mudanças naturais } \\
\text { em uma possível } \\
\text { influência da variável } \\
\text { causa sobre mudanças } \\
\text { em uma possível } \\
\text { variável efeito. }\end{array}$ & $\begin{array}{l}\text { - Pergunte aos estudantes como eles iriam } \\
\text { testar efeitos de mudanças em uma variável } \\
\text { que podem levar a efeitos prejudiciais; por } \\
\text { exemplo, efeitos de fumar maconha na tosse de } \\
\text { adolescentes. Através da discussão, ajude-os a } \\
\text { compreender a necessidade de estudar variáveis } \\
\text { que mudam naturalmente, tanto por razões } \\
\text { éticas quanto práticas. Com exemplos, explique } \\
\text { a eles como os estudos funcionam; } \\
\text { - Forneça exemplos de estudos, com dados } \\
\text { amostrais; por exemplo, a quantidade de } \\
\text { fumantes vs as taxas de câncer; populações } \\
\text { predador-presa vs tempo. }\end{array}$ & $\begin{array}{l}\text { - Mostre aos estudantes como medir } \\
\text { diversas variáveis sobre os seres } \\
\text { humanos e em seguida, conduza-os } \\
\text { a realizar um estudo destas variáveis, } \\
\text { construindo gráficos para pares de } \\
\text { variáveis que eles acreditam serem } \\
\text { causalmente relacionadas; por } \\
\text { exemplo, idade, sexo, comprimento } \\
\text { do dedo etc., como eles afetam o } \\
\text { tempo de reação etc.; } \\
\text { - Peça aos estudantes para projetar } \\
\text { e realizar estudos com base em listas } \\
\text { variáveis de causa e efeito. }\end{array}$ \\
\hline
\end{tabular}




\begin{tabular}{|c|c|c|}
\hline $\begin{array}{l}\text { Habilidades de } \\
\text { Investigação, Projeto, } \\
\text { Comunicação \& } \\
\text { Ações }\end{array}$ & $\begin{array}{c}\text { MODELAGEM } \\
\text { (Demonstrações interativas do professor) }\end{array}$ & $\begin{array}{c}\text { PRÁTICA GUIADA } \\
\text { (Prática do estudante, com assistência } \\
\text { do professor) }\end{array}$ \\
\hline $\begin{array}{l}\text { Desenvolvimento de } \\
\text { Gráficos, mapas e } \\
\text { esquemas }\end{array}$ & $\begin{array}{l}\text { - Demonstre, preferivelmente com dados que } \\
\text { eles tenham coletado, como construir estas } \\
\text { representações. }\end{array}$ & $\begin{array}{l}\text { - Proporcione dados aos estudantes; } \\
\text { peça-lhes para preparar gráficos, } \\
\text { mapas e esquemas. }\end{array}$ \\
\hline $\begin{array}{l}\text { Desenvolver } \\
\text { conclusões prudentes }\end{array}$ & $\begin{array}{l}\text { - Proporcionar aos estudantes investigações por } \\
\text { amostragem, com dados e, em seguida, inferir } \\
\text { conclusões. Enfatizar que o projeto ou desenho } \\
\text { do teste deve ser avaliado e criticado antes da } \\
\text { extração da conclusão com base nos dados. }\end{array}$ & $\begin{array}{l}\text { - Forneça aos estudantes amostras } \\
\text { de pesquisas e, então, peça-lhes para } \\
\text { tirar conclusões prudentes. }\end{array}$ \\
\hline $\begin{array}{l}\text { Preparar relatórios } \\
\text { escritos }\end{array}$ & $\begin{array}{l}\text { - Proporcionar aos estudantes um checklist } \\
\text { para a produção de relatórios, assim como um } \\
\text { exemplo simples de relatório. }\end{array}$ & $\begin{array}{l}\text { - Forneça aos estudantes exemplos } \\
\text { de relatórios para avaliar cheklists. }\end{array}$ \\
\hline Debater conclusões & $\begin{array}{l}\text { - Proporcionar aos estudantes uma lista de } \\
\text { sugestões para debater de forma eficaz e usar } \\
\text { estes, como uma aula, para criticar um debate } \\
\text { gravado em vídeo. }\end{array}$ & $\begin{array}{l}\text { - Peça aos estudantes para debater } \\
\text { questões provavelmente importantes } \\
\text { para eles; por exemplo, o mérito de } \\
\text { pedalar ou caminhar para a escola vs } \\
\text { ir em um carro. }\end{array}$ \\
\hline $\begin{array}{l}\text { Distinguir objetivos de } \\
\text { pesquisa científica de } \\
\text { objetivos de projetos } \\
\text { tecnológicos }\end{array}$ & $\begin{array}{l}\text { - Ajude os estudantes a distinguir entre } \\
\text { interesses (objetivos) "científicos" e } \\
\text { "tecnológicos", discutindo com eles o que } \\
\text { "cientistas" poderiam fazer com objetos; por } \\
\text { exemplo, balões. }\end{array}$ & $\begin{array}{l}\text { - Peça aos estudantes para } \\
\text { determinar um objetivo de pesquisa } \\
\text { (científico) e um objetivo tecnológico } \\
\text { para cada um dos seguintes } \\
\text { fenômenos; por exemplo, sementes. }\end{array}$ \\
\hline Determinar problemas & $\begin{array}{l}\text { - Mostre que "problemas" são muitas vezes as } \\
\text { relações entre causa e efeito com resultados } \\
\text { "ruins". Mostre a eles como as "neuras" são } \\
\text { assim. }\end{array}$ & $\begin{array}{l}\text { - Peça aos estudantes para fazer uma } \\
\text { chuva de ideias sobre suas "neuras" } \\
\text { e decompor cada uma delas em uma } \\
\text { causa e um efeito "ruim". }\end{array}$ \\
\hline $\begin{array}{l}\text { Desenvolver soluções/ } \\
\text { invenções }\end{array}$ & $\begin{array}{l}\text { - Aponte que soluções podem ser desenvolvidas } \\
\text { por: i) uma chuva de ideias (brainstorming) sobre } \\
\text { as possíveis causas dos resultados "ruins" e, em } \\
\text { seguida, a partir da superação destas causas; ii) } \\
\text { uma combinação de velhas invenções com novas } \\
\text { formas de fazer etc. } \\
\text { - Aponte que inventar envolve tentativa e } \\
\text { erro e compromissos para alcançar a "melhor" } \\
\text { combinação de resultados; por exemplo, } \\
\text { inventar uma bicicleta de baixo peso pode fazer } \\
\text { com que ela seja frágil. }\end{array}$ & $\begin{array}{l}\text { - Coloque os estudantes para fazer } \\
\text { uma chuva de ideias sobre inventos } \\
\text { "velhos" e combinar estes inventos de } \\
\text { maneiras novas e úteis; } \\
\text { - Peça aos estudantes para } \\
\text { desenvolver invenções que atinjam } \\
\text { dois resultados concorrentes; por } \\
\text { exemplo, um paraquedas que desce } \\
\text { lentamente e com precisão. }\end{array}$ \\
\hline $\begin{array}{l}\text { Avaliar os efeitos } \\
\text { sociais e ambientais } \\
\text { negativos das } \\
\text { invenções }\end{array}$ & $\begin{array}{l}\text { - Discutir os efeitos negativos que eles associam } \\
\text { com várias invenções. Fornecer alguns estudos } \\
\text { de caso de outras invenções; por exemplo, danos } \\
\text { ao ouvido relacionados com música alta. } \\
\text { - Descrever estudos experimentais e de } \\
\text { correlação para avaliar invenções. }\end{array}$ & $\begin{array}{l}\text { - Peça aos estudantes para estudar } \\
\text { os efeitos de soluções salinas no } \\
\text { crescimento de feijoeiros (isto é, } \\
\text { imitando efeitos de escoamento do } \\
\text { sal da estrada); } \\
\text { - Coloque os estudantes para } \\
\text { conduzir um estudo comparativo } \\
\text { entre fumantes e não fumantes. }\end{array}$ \\
\hline $\begin{array}{l}\text { Desenvolvimento e } \\
\text { execução de ações } \\
\text { para melhorar as } \\
\text { coisas }\end{array}$ & $\begin{array}{l}\text { - Mostre aos estudantes exemplos de RiNA de } \\
\text { outros, executadas para melhorar as situações } \\
\text { de indivíduos, sociedades e/ou ambientes; por } \\
\text { exemplo, o estudo da reciclagem levando a } \\
\text { ações. }\end{array}$ & $\begin{array}{l}\text { - Peça aos estudantes para projetar } \\
\text { estudos e fazer pesquisas na } \\
\text { Internet para aprender sobre o } \\
\text { tabagismo; e, em seguida, que eles } \\
\text { projetem e desenvolvam uma ação } \\
\text { antitabagismo. }\end{array}$ \\
\hline
\end{tabular}

Fonte: Bencze (2015). 


\section{Apêndice C - Exemplo de atividade sobre "experimentos"}

Nome

Ciência: planejando experimentos

Ideias de cientistas e inventores

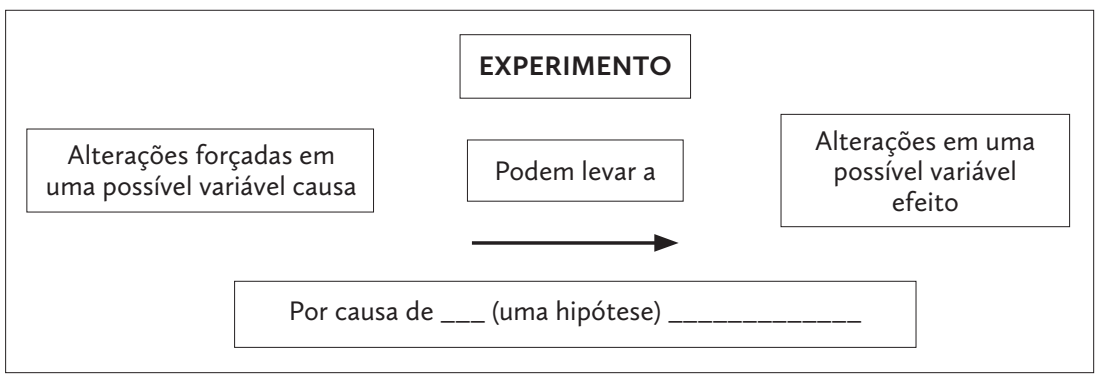

Para que as pessoas acreditem em certas ideias, elas geralmente querem ver evidências. Na ciência e na inovação, frequentemente elas vem de experimentos. Um "experimento" é um teste de uma previsão na qual uma possível variável causa é forçada a mudar para que nós possamos verificar o que esta mudança causa a uma possível variável efeito. Em vez de esperar que dois produtos químicos misturem-se um ao outro, por exemplo, nós forçaríamos diferentes quantidades da mistura. Ao longo dos anos, cientistas e inventores tentaram muitos modos diferentes de desenhar ou construir experimentos. $O$ exemplo abaixo mostra alguns tipos de métodos que muitos tentam seguir ao planejar experimentos úteis.

\section{Agora, faça você!}

Um exemplo de experimento para testar como diferentes tamanhos (circunferências) de balões influenciam na rapidez com que eles caem é mostrado abaixo. Seguindo as sugestões para o desenho/ projeto deste experimento, planeje um experimento sobre um tópico sugerido por seu professor.

\begin{tabular}{|c|c|c|}
\hline Fatores do desenho & Amostra do experimento & Teste \\
\hline Use diferentes valores da possível variável causa. & Circunferências $(\mathrm{cm}) 10,15,20,25,30,35,40 \mathrm{~cm}$. & \\
\hline $\begin{array}{l}\text { Use ao menos cinco cópias de cada quantidade } \\
\text { da possível variável causa. }\end{array}$ & $\begin{array}{l}\text { Haverá cinco balões similares inflados a diferentes } \\
\text { tamanhos: } 10,15,20,25,30,35,40 \mathrm{~cm} \text {. }\end{array}$ & \\
\hline Meça as possíveis variáveis causa e efeito. & $\begin{array}{l}\text { Tamanhos medidos com fitas métricas; tempo } \\
\text { para pouso com cronômetro e uma pessoa } \\
\text { dizendo, "comece!" e "termine!" }\end{array}$ & \\
\hline Repita cada mensuração e encontre a média. & $\begin{array}{l}\text { Duas pessoas farão cada mensuração; então será } \\
\text { calculada a média. }\end{array}$ & \\
\hline $\begin{array}{l}\text { Mantenha todas as outras variáveis causas } \\
\text { conhecidas não modificadas. }\end{array}$ & $\begin{array}{l}\text { Use o mesmo tipo de balão; solte-os da mesma } \\
\text { altura; certifique-se de que não há nenhuma brisa; } \\
\text { certifique-se de que a temperatura é a mesma. }\end{array}$ & \\
\hline Mensure uma segunda possível variável efeito. & $\begin{array}{l}\text { Meça a distância percorrida por um balão a partir } \\
\text { de um certo ponto. }\end{array}$ & \\
\hline $\begin{array}{l}\text { Planeje fazer descrições de possíveis variáveis } \\
\text { causa e efeito. }\end{array}$ & $\begin{array}{l}\text { Descreva a cor e o formato dos balões de } \\
\text { diferentes tamanhos; observe qualquer oscilação à } \\
\text { medida em que o balão cai. }\end{array}$ & \\
\hline Planeje uma tabela de coleta de dados. & Refira-se a uma tabela do professor. & \\
\hline
\end{tabular}




\title{
Apêndice D - Exemplo de atividade sobre "experimentos".
}

\author{
$\mathrm{SCH}_{3} \mathrm{U}$ - Introdução a Estudos de Correlação
}

Sr. Krstovic

\section{Parte I) Introdução a Estudos de Correlação e de Variáveis}

Um experimento é uma atividade em que uma ou mais variáveis independentes (causa) são forçadas a mudar. Por exemplo, para testar o efeito de diferentes tipos de solo sobre o crescimento de plantas de feijão, podemos conduzir um experimento usando diferentes tipos de solos (variável independente causa) e medir a altura resultante da planta de feijão (variável dependente - efeito).

Ainda, nós podemos encontrar algumas plantas de feijão na natureza, medir suas alturas e examinar o tipo de solo em cada. Nós podemos, então, ver se há uma relação entre a altura da planta e o tipo de solo. Este tipo de pesquisa seria um estudo, não um experimento. Permite-se que a variável independente (causa) mude naturalmente. Também seria um estudo de correlação, porque nós estaríamos comparando (correlacionando) como mudanças em uma variável (por exemplo, tipos de solo) pode afetar mudanças em outra variável (por exemplo, altura da planta).

Estudos de correlação são úteis quando não é recomendado eticamente medir as mudanças na variável efeito, resultante de certas variáveis causa. Com tipos de solo e crescimento de plantas de feijão seria melhor conduzir um experimento. Entretanto, se desejamos estudar a relação entre fumo e pessoas que desenvolvem câncer de pulmão, então nós conduziríamos um estudo. Não é correto (eticamente) forçar um grupo de pessoas a fumar e observar se eles desenvolvem câncer de pulmão.

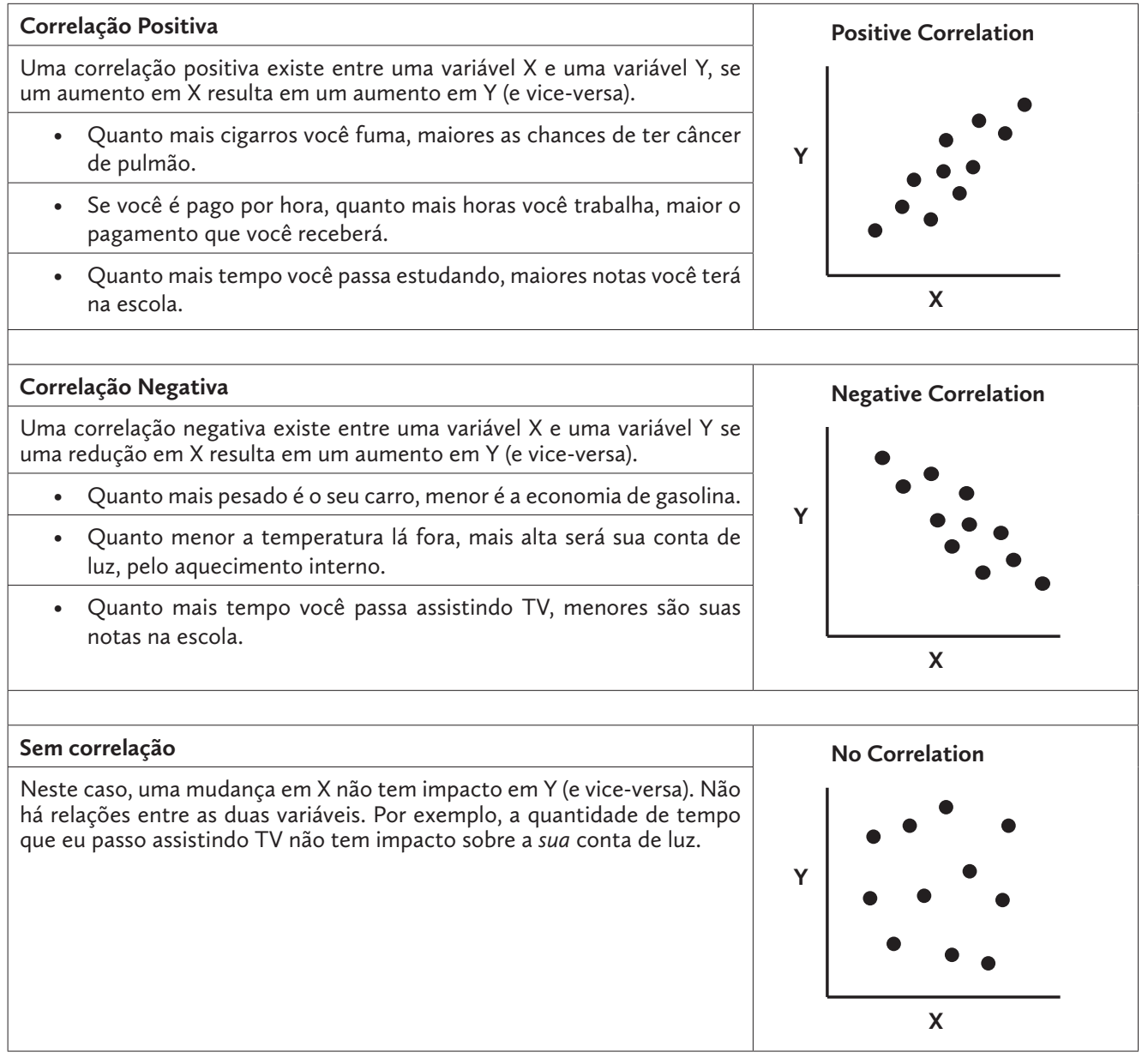

554 | Larry Bencze / Sarah El Halwany / Mirjan Krstovic / Minja Milanovic / Christina Phillips / Majd Zouda 
1) Usando a seguinte tabela, ligue cada variável causa a sua variável efeito. Pode existir mais de uma resposta possível.

\begin{tabular}{|l|l|}
\hline Variáveis causa (independentes) & Variáveis efeito (dependentes) \\
\hline Vegetarianismo & Audição de adolescentes \\
\hline Música de rock & Aprendizagem de adolescentes \\
\hline Exercício & Altura da planta \\
\hline Hormônios & Crescimento de bactérias \\
\hline Drogas & Comportamento agressivo \\
\hline Assistir TV & Forma física \\
\hline Temperatura & Força muscular \\
\hline
\end{tabular}

2) Como você poderia conduzir as investigações a seguir? Você realizaria um experimento ou conduziria um estudo? Identifique as variáveis independente (VI) e dependente (VD) em cada caso. Além disso, pense naquilo que você teria que controlar!

a) Os efeitos do consumo de cigarros sobre a frequência de tosse

\begin{tabular}{|l|l|l|l|}
\hline Estudo & Experimento & VI: & VD: \\
\hline
\end{tabular}

b) Solubilidade do sal em várias temperaturas

\begin{tabular}{|l|l|l|l|}
\hline Estudo & Experimento & VI: & VD: \\
\hline
\end{tabular}

c) Quantidade de tempo em frente ao computador e qualidade do sono

\begin{tabular}{|l|l|l|l|}
\hline Estudo & Experimento & VI: & VD: \\
\hline
\end{tabular}

d) O efeito do $\mathrm{pH}$ sobre a corrosão do metal

\begin{tabular}{|l|l|l|l|}
\hline Estudo & Experimento & VI: & VD: \\
\hline
\end{tabular}

e) Tempo que você passou jogando video game e suas notas na escola

\begin{tabular}{|l|l|l|l|}
\hline Estudo & Experimento & VI: & VD: \\
\hline
\end{tabular}


Parte II) Preparando-se para executar um estudo - Praticando a coleta de dados em aula e determinando a correlação entre duas variáveis

Questão 1: há correlação entre gênero e memória?

Questão 2: há correlação entre tamanho da mão e habilidade para equilibrar uma régua de um metro, verticalmente na ponta do dedo médio da mão com a qual você escreve?

Tabela de coleta de dados:

\begin{tabular}{|l|l|l|l|}
\hline $\begin{array}{l}\text { Nome do estudante } \\
\text { (Gênero) }\end{array}$ & $\begin{array}{l}\text { Número médio de } \\
\text { cartas memorizadas }\end{array}$ & $\begin{array}{l}\text { Comprimento } \\
\text { da mão (cm) }\end{array}$ & $\begin{array}{l}\text { Tempo em } \\
\text { equilíbrio (s) }\end{array}$ \\
\hline & & & \\
\hline & & & \\
\hline & & & \\
\hline & & & \\
\hline & & & \\
\hline & & & \\
\hline
\end{tabular}

Análise:

1) Construa um gráfico de barras para mostrar o número médio de cartas memorizadas por mulheres e homens. Diga se há qualquer correlação entre gênero e memória em nossa turma.

2) Construa um gráfico com pontos plotados do tempo de equilíbrio (eixo-Y) e tamanho da mão (eixo-X). Determine se há correlação entre tamanho da mão e tempo de equilíbrio para os estudantes em nossa turma. 


\title{
Apêndice E - Projeto de Ação Negociada e informada por pesquisa (RiNA) sobre mudança climática
}

\author{
Ciências ( $1^{\circ}$ ano do ensino médio*)
}

\section{Introdução}

A mudança climática é uma das questões mais importantes que a humanidade enfrenta e continuará a enfrentar no futuro. Neste projeto, você terá uma oportunidade de realizar ações para abordar algumas das questões relacionadas à mudança climática.

Passos para o Projeto de Ação sobre CTSA e mudança climática

1) Selecionar seu grupo e sua questão: recentemente você completou a atividade da pegada de carbono na qual você determinou a quantidade de dióxido de carbono que você produz através de várias atividades, e como sua pegada de carbono se compara à média no seu país. Nesta atividade você respondeu questões que se relacionam às questões do dia a dia como transporte, consumo de água, reciclagem, alimentação etc. Você e seu grupo (máximo de 4 pessoas) irão escolher uma destas atividades que contribui para a mudança climática, e seguir os passos esboçados aqui para completar este projeto de RiNA. Dois grupos podem explorar a mesma questão.

2) Expressando as suas ideias: antes de começar uma nova pesquisa sobre sua questão selecionada que contribui para a mudança climática, você deve expressar o que você já sabe sobre a questão (por exemplo, o que faz disso uma questão relevante? Quem são os grupos poderosos que suportam e que se opõem a esta questão? Quais são as consequências sobre o bem-estar de indivíduos, sociedades e ambientes?). Inclua suas ideias sobre como abordar alguns dos problemas que surgem a partir destas questões (por exemplo, Como encorajamos mais pessoas a reciclar na escola durante o almoço?)

3) Pesquisa secundária: aprenda mais sobre a questão. Você terá algum tempo em aula para conduzir uma pesquisa na internet (alguma informação pode ser encontrada também em seu livro didático). Você deve abordar as seguintes perguntas ou áreas sobre a questão:

i. Como a sua questão se relaciona à mudança climática? Por exemplo, como a sua escolha de consumir mais carne aumenta a sua pegada de carbono? Explique os conceitos científicos relevantes (por exemplo, efeito estufa antropogênico).

ii. Quem são os atores sociais (stakeholders) relevantes? Identifique grupos poderosos que apoiam a questão (por exemplo, companhias de petróleo, governos) e grupos que se opõem à questão (por exemplo, ambientalistas, ativistas). Explique as posições deles. Declare a sua posição sobre a questão.

iii. Pesquise ao menos três (3) fatos interessantes! Por exemplo, se você está explorando a questão do transporte, quantos carros estão em circulação por dia? Quanto $\mathrm{CO}_{2}$ é emitido por carro? Se você está aprendendo sobre consumo de água, que país consome mais água por pessoa? Quanta água seria economizada se chuveiros de baixa pressão são usados ao invés de chuveiros de alta pressão?

iv. Explorando consequências adicionais e ações: quais seriam as outras consequências que a sua questão selecionada pode ter sobre o bem-estar de indivíduos, sociedades e ambientes? Por exemplo, muitas aves se enganam com tampas de garrafas d'água e sacolas de plástico, e por isso, morrem após comer tais objetos. Portanto, é muito importante que estes itens não terminem indo para os nossos ambientes naturais. Também, você deve buscar o que já tem sido feito para abordar sua questão. Por exemplo, veículos híbridos são produzidos como alternativas para veículos movidos apenas a gasolina.

4) Conduzindo um estudo: seu grupo desenvolverá um levantamento de informações consistindo de três a cinco questões para aprender mais sobre o assunto. Sua variável independente (variável causa) pode ser gênero, idade ou nível de estudo. Sua amostra deve ser composta de aproximadamente 25-30 estudantes, no entanto, quanto maior o tamanho da amostra mais confiáveis serão seus resultados.

* Nota do tradutor: traduzimos para o equivalente no Brasil. No original, os autores se referem ao $10^{\text {th }}$ grade (Sophomore), do ano escolar norte-americano. 
5) Análise dos dados: você deve calcular os seus resultados, colocar os dados em um gráfico (por exemplo, em um gráfico de barras) para mostrar se há alguma correlação entre gênero (ou idade/ nível de educação etc.) e quaisquer variáveis dependentes (variáveis efeito) que você estudou (por exemplo, modos de transporte, escolhas alimentares etc.).

6) Proponha e execute suas ações: você e seu grupo proporão cursos práticos de ação para abordar suas questões (por exemplo, desenvolver um folheto ou vídeo, influenciar grupos poderosos, criar cartazes atraentes sobre reciclagem na escola, escrever uma carta a um jornal local etc.). Sua pesquisa (tanto em buscas de internet quanto em estudos de correlação) deve informar a escolha de sua ação.

7) Agindo: uma vez que você preparou suas ações, você terá que colocá-las em prática. Esta é a parte emocionante! Se você fez um folheto, você precisa distribuir diretamente às pessoas na escola, ou na comunidade. Se você fez um vídeo, você pode postá-lo no YouTube e pedir a seus amigos para compartilhá-lo nas mídias sociais.

8) Defenda suas ações: durante a aula, sua equipe terá 10-15 minutos para defender suas ações. Você nos contará que questão da mudança climática você estudou, o que você aprendeu do estudo que você conduziu e que ações seu grupo executou para abordar a questão.

9) Entregue o seu projeto de ação sobre a mudança climática: cada pessoa terá que entregar um relatório escrito após a finalização do seu projeto de ação sobre CTSA. Por favor, veja a ficha de avaliação para uma lista de itens que precisariam ser abordados no seu relatório.

\section{Critérios de sucesso para pesquisa secundária (em internet, livros didáticos, artigos etc.)} (1- Emergente; 2 - Proficiente; 3 - Altamente treinado; 4 - Exemplar)

\begin{tabular}{|c|c|c|}
\hline \multirow{4}{*}{ 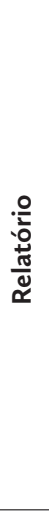 } & $\begin{array}{l}\text { 1.1. Introdução: a questão CTSA é claramente descrita em suas próprias palavras } \\
\text { 1.2. Conexão com a mudança climática: a conexão da questão com a mudança } \\
\text { climática é evidente na sua descrição } \\
\text { 1.3. Fatos e detalhes: ao menos três fatos e detalhes interessantes sobre sua } \\
\text { questão estão presentes }\end{array}$ & 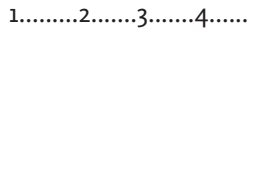 \\
\hline & $\begin{array}{l}\text { 2.1 - } 2.3 \text { Consequências negativas: explicações claras e completas de uma } \\
\text { consequência negativa sobre o bem-estar de indivíduos, sociedades e/ou } \\
\text { ambientes e sugestões claras (ao menos uma) para lidar com a questão }\end{array}$ & 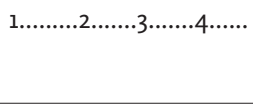 \\
\hline & $\begin{array}{l}\text { 3.1 Tomadores de decisão importantes/atores sociais poderosos: você identificou } \\
\text { claramente os atores sociais poderosos (tomadores de decisão/stakeholders } \\
\text { relevantes) e suas influências }\end{array}$ & $1, \ldots \ldots \ldots .2 \ldots \ldots .3 \cdots \cdots \cdot 4 \cdots \cdots$ \\
\hline & $\begin{array}{l}\text { A informação que você pesquisou é relevante, detalhada e precisa com } \\
\text { referências presentes (ao menos duas); está sintetizada em aproximadamente } \\
400-500 \text { palavras (ou 1-1,5 página, espaçamento duplo) }\end{array}$ & 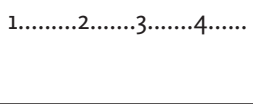 \\
\hline \multicolumn{2}{|r|}{ NIVVL GERAL DE ALCANCE PARA A PESQUISA SECUNDÁRIA } & $1 \ldots \ldots \ldots . .2 \ldots \ldots . \cdots 3 \cdots \cdots . \cdots \cdots$ \\
\hline \multicolumn{3}{|c|}{ Critérios de sucesso para pesquisa primária (estudos de correlação) } \\
\hline \multirow{5}{*}{ 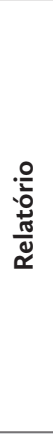 } & $\begin{array}{l}\text { 4.1. Foco do estudo: o foco do estudo estava claramente enunciado e suas } \\
\text { variáveis (causa/efeito) são identificadas. O método para o seu estudo está } \\
\text { claramente descrito em um parágrafo curto (cerca de } 100 \text { palavras) } \\
\text { 4.2. Análise de dados: seus dados são claramente mostrados nas tabelas; há } \\
\text { gráficos apropriados com títulos claros, eixos identificados e uma legenda }\end{array}$ & 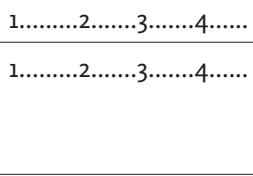 \\
\hline & \multirow{4}{*}{$\begin{array}{l}\text { 5.1. Sumário de resultados: sintetize seus resultados em um parágrafo curto } \\
\text { (cerca de } 100 \text { palavras) } \\
\text { 5.2. Interpretação dos resultados: proponha uma explicação clara e profunda para } \\
\text { seus resultados (cerca de } 100 \text { palavras) } \\
\text { 5.3. Sugestões para melhorias: discuta possíveis limitações nos seus resultados/ } \\
\text { métodos e sugira ao menos um caminho para melhorar seu estudo (cerca de } 100 \\
\text { palavras) }\end{array}$} & 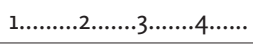 \\
\hline & & 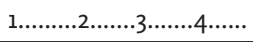 \\
\hline & & 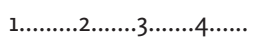 \\
\hline & & \\
\hline \multicolumn{2}{|r|}{ NIIVEL GERAL DE ALCANCE PARA A PESQUISA PRIMÁRIA } & 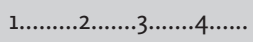 \\
\hline
\end{tabular}


Critérios de sucesso para pesquisa secundária (em internet, livros didáticos, artigos etc.) (1- Emergente; 2 - Proficiente; 3 - Altamente treinado; 4 - Exemplar)

\section{Critérios de sucesso para as ações propostas e executadas}

\begin{tabular}{|c|c|c|}
\hline \multirow{2}{*}{$\frac{\frac{n}{\pi}}{\frac{\pi}{2}}$} & $\begin{array}{l}\text { Suas ações propostas são lógicas e com um foco claro que é negociado e } \\
\text { informado por pesquisa }\end{array}$ & 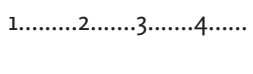 \\
\hline & $\begin{array}{l}\text { Seus materiais disponíveis são apresentáveis (boa qualidade), completos e estão } \\
\text { incluídos em seu relatório (por exemplo, uma amostra de um folheto, um link para } \\
\text { seu vídeo no YouTube etc.) }\end{array}$ & \\
\hline \multirow{3}{*}{ 象 } & $\begin{array}{l}\text { 6.1. Implementação da ação: descreva como sua ação foi (ou será) implementada } \\
\text { e como ela contribuiu/contribuirá para uma mudança positiva para o bem-estar } \\
\text { de indivíduos, sociedades e ambientes }\end{array}$ & 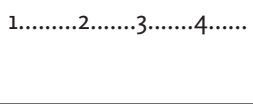 \\
\hline & $\begin{array}{l}\text { 7.1. Reflexão: reflita sobre experiência de aprendizagem abordando as seguintes } \\
\text { questões: }\end{array}$ & 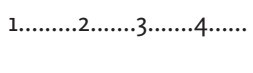 \\
\hline & $\begin{array}{l}\text { i) O que você aprendeu executando este projeto? } \\
\text { ii) De que modo este projeto foi diferente de outros projetos que você já } \\
\text { participou no passado em ciências (ou outros cursos)? } \\
\text { iii) Você estaria interessado em executar um outro projeto como este em sala de } \\
\text { aula? Por que sim ou por que não? } \\
\text { (observação: estas questões não têm uma resposta certa ou errada, sua resposta } \\
\text { honesta e completa lhe dará pontuação total) }\end{array}$ & \\
\hline \multicolumn{2}{|r|}{ NÍVEL GERAL DE ALCANCE PARA O PLANO DE AÇÃO } & 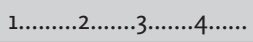 \\
\hline \multicolumn{3}{|c|}{ Avaliação da comunicação oral } \\
\hline \multicolumn{3}{|c|}{ Sua parte da apresentação alcançou os seguintes critérios } \\
\hline \multicolumn{2}{|r|}{ Foi organizada, lógica e numa duração de tempo apropriada } & 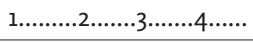 \\
\hline \multicolumn{2}{|r|}{ Você falou claramente, em bom tom - foi fácil ouvir e entender você } & 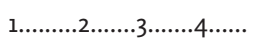 \\
\hline \multicolumn{2}{|r|}{$\begin{array}{l}\text { Você estabeleceu um bom contato visual com um mínimo de leitura ou uso dos } \\
\text { apontamentos escritos }\end{array}$} & 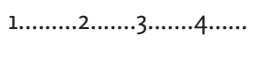 \\
\hline \multicolumn{2}{|r|}{$\begin{array}{l}\text { Você foi confiante com relação à informação que apresentou e se questionado sobre } \\
\text { algo, respondeu bem }\end{array}$} & 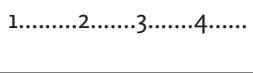 \\
\hline \multicolumn{2}{|r|}{ O conteúdo da apresentação foi preciso e apropriado para a audiência } & 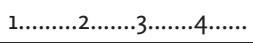 \\
\hline \multicolumn{2}{|r|}{ NIVEL GERAL DE ALCANCE PARA A COMUNICAÇÃO ORAL } & 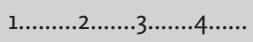 \\
\hline
\end{tabular}

